\title{
Chelating NHC Ruthenium(II) Complexes as Robust Homogeneous Hydrogenation Catalysts
}

\author{
Claudio Gandolfi, ${ }^{\dagger}$ Marion Heckenroth,${ }^{\dagger}$ Antonia Neels, ${ }^{\dagger}$ Gábor Laurenczy, ${ }^{\S}$ and \\ Martin Albrecht*,, \\ ${ }^{\dagger}$ Department of Chemistry, University of Fribourg, Chemin du Musée 9, CH-1700 Fribourg, Switzerland, \\ ${ }^{\star}$ XRD Application Lab, CSEM, Rue Jaquet-Droz 1, CH-2002 Neuchâtel, Switzerland, and ${ }^{\S}$ Institut des \\ Sciences et Ingénierie Chimiques, Ecole Polytechnique Fédérale de Lausanne (EPFL), CH-1015 Lausanne,
} Switzerland

\begin{abstract}
A series of ruthenium(II) complexes have been prepared by using bidentate chelating $\mathrm{N}$-heterocyclic carbene (NHC) ligands that feature different donor groups $\mathrm{E}$ ( $\mathrm{E}=$ olefin, thioether, carboxylate, and NHC). Rigid coordination of all donor sites was concluded from NMR spectroscopy, and the electronic impact of the donor group was evaluated by electrochemical analyses. The chelating donor group had a strong influence on the activity of the metal center in catalyzing direct hydrogenation of styrene. A thioether group or a second NHC donor site essentially deactivates the metal center. Complexes comprising a NHC tethered with an olefin or a carboxylate group showed appreciable activity, though only the carboxylate-functionalized system proved to be a precursor for homogeneous hydrogenation. According to in situ high-pressure NMR analyses, complexes featuring a carboxylate chelating group are remarkably resistant toward reductive elimination even under strongly reducing conditions and may, therefore, be used repeatedly.
\end{abstract}

\section{Introduction}

$\mathrm{N}-\mathrm{Heterocyclic}$ carbenes (NHCs), originally considered as substitutes for ubiquitous phosphines in transition metal catalysis, ${ }^{1}$ have emerged as powerful ligands that are in many aspects complementary to phosphines. ${ }^{2}$ They impose a different steric environment at the active metal center, and they are generally robust to oxidations, ${ }^{3}$ thus preventing catalyst degradation in processes that are performed under aerobic conditions. Hence, extremely active NHC metal complexes have been developed for cross-coupling reactions, ${ }^{4}$ olefin metathesis, ${ }^{5}$ and transfer hydrogenation catalysis. ${ }^{6}$ In contrast, application of $\mathrm{NHC}$ ligands in direct hydrogenation-one of

*To whom correspondence should be addressed. E-mail: martin. albrecht@unifr.ch. Fax:+41-263009738.

(1) Hermann, A. W. Angew. Chem., Int. Ed. 2002, 41, 1290.

(2) (a) Bertrand, G., Ed. J. Organomet. Chem. 2005, 690 (24-25). (b) Crabtree, R. H., Ed. Coord. Chem. Rev. 2007, 251 (5-6). (c) Glorius, F., Ed. Top. Organomet. Chem. 2007, 21. (d) Nolan, S. P., Ed. N-Heterocyclic Carbenes in Synthesis; Wiley-VCH: Weinheim, 2006. (e) Hahn, F. E.; Jahnke, M. C. Angew. Chem., Int. Ed. 2008, 47, 3122.

(3) (a) Konnick, M. K.; Guzei, I. A.; Stahl, S. S. J. Am. Chem. Soc. 2003, 125, 10212. (b) Sigman, M. S.; Jensen, D. R. Acc. Chem. Res. 2006, $39,221$.

(4) (a) Kantchev, E. A. B.; O'Brien, C. J.; Organ, M. G. Angew. Chem., Int. Ed. 2007, 46, 2768. (b) Marion, N.; Nolan, S. P. Acc. Chem. Res. 2008, 41,1440 .

(5) (a) Scholl, M.; Trnka, T. M.; Morgan, J. P.; Grubbs, R. H. Tetrahedron Lett. 1999, 40, 2247. (b) Huang, J.; Schanz, H. Z.; Stevens, E. D.; Nolan, S. P. Organometallics 1999, 18, 5375. (c) Grubbs, R. H. Angew. Chem., Int. Ed. 2006, 45, 3760.

(6) (a) Albrecht, M.; Miecznikowski, J. R.; Samuel, A.; Faller, J. W.; Crabtree, R. H. Organometallics 2002, 21, 3596. (b) Hahn, F. E.; Holtgrewe, C.; Pape, T.; Martin, M.; Sola, E.; Oro, L. A. Organometallics 2005, 24, 2203. the particularly successful domains of phosphines in transition metal catalysis ${ }^{7}$ - has been limited thus far. ${ }^{8}$ This restriction largely originates from the high susceptibility of the $\mathrm{M}-\mathrm{C}_{\mathrm{NHC}}$ bond toward reductive elimination under reducing conditions. ${ }^{9}$ Imidazolium elimination and heterogenization of the catalyst

(7) (a) Osborn, J. A.; Jardine, F. H.; Young, J. F.; Wilkinson, G. J. Chem. Soc. A 1966, 1711. (b) Kagan, H. B.; Dang, T. P. J. Am. Chem. Soc. 1972, 94, 6429. (c) Fryzuk, M. B.; Bosnich, B. J. Am. Chem. Soc. 1977, 99 , 6262. (d) Crabtree, R. Acc. Chem. Res. 1979, 12, 331. (e) Chan, A. S. C.; Pluth, J. J.; Halpern, J. J. Am. Chem. Soc. 1980, 102, 5952. (f) Knowles, W. S. Angew. Chem., Int. Ed. 2002, 41, 1998. (g) Noyori, R. Angew. Chem., Int. Ed. 2002, 41, 2008.

(8) (a) Powell, M. T.; Hou, D.-R.; Perry, M. C.; Cui, X.; Burgess, K. J. Am. Chem. Soc. 2001, 123, 8878. (b) Sprenger, J. W.; Wassenaaar, J.; Clement, N. D.; Cavell, K. J.; Elsevier, C. J. Angew. Chem., Int. Ed. 2005, 44, 2026. (c) Baskakov, D.; Herrmann, W. A.; Herdtweck, E.; Hoffmann, S. D. Organometallics $\mathbf{2 0 0 7}, 26,626$. Reduced activity and even catalyst decomposition have been noted explicitly, see: (d) Chen, D.; Banphavichit, V.; Reibenspies, J.; Burgess, K. Organometallics 2007, 26, 855. (e) Camm, K. D.; Martinez Castro, N.; Liu, Y.; Czechura, P.; Snelgrove, J. L.; Fogg, D. E. J. Am. Chem. Soc. 2007, 129, 4168.

(9) (a) Cavell, K. J.; McGuinness, D. S. Coord Chem. Rev. 2004, 248 , 671. (b) Crudden, C. M.; Allen, D. P. Coord. Chem. Rev. 2004, 248, 2247. For other bond cleavege mechanisms, see also: (c) Praetorius, J. M.; Crudden, C. M. Dalton Trans. 2008, 31, 4079.

(10) For selected examples, see: (a) McGuinness, D. S.; Mueller, W.; Wasserscheid, P.; Cavell, K. J.; Skelton, B. W.; White, A. H.; Englert, U. Organometallics 2002, 21, 175. (b) Courchay, F. C.; Sworen, J. C.; Ghiviriga, I.; Abboud, K. A.; Wagener, K. B. Organometallics 2006, 25, 6074. (c) Arisawa, M.; Terada, Y.; Takahashi, K.; Nakagawa, M.; Nishida, A. J. Org. Chem. 2006, 71, 4255. (d) Chantler, V. L.; Chatwin, S. L.; Jazzar, R. F. R.; Mahon, M. F.; Saker, O.; Whittlesey, M. K. Dalton Trans. 2008, 2603. (e) Saker, O.; Mahon, M. F.; Warren, J. E.; Whittlesey, M. K. Organometallics 2009, 28, 1976.

(11) For examples of stable metal hydrides, see: Jazzar, R. F. R.; Macgregor, S. A.; Mahon, M. F.; Richards, S. P.; Whittlesey, M. K. J. Am. Chem. Soc. 2002, 124, 4944. 
Scheme $1^{a}$

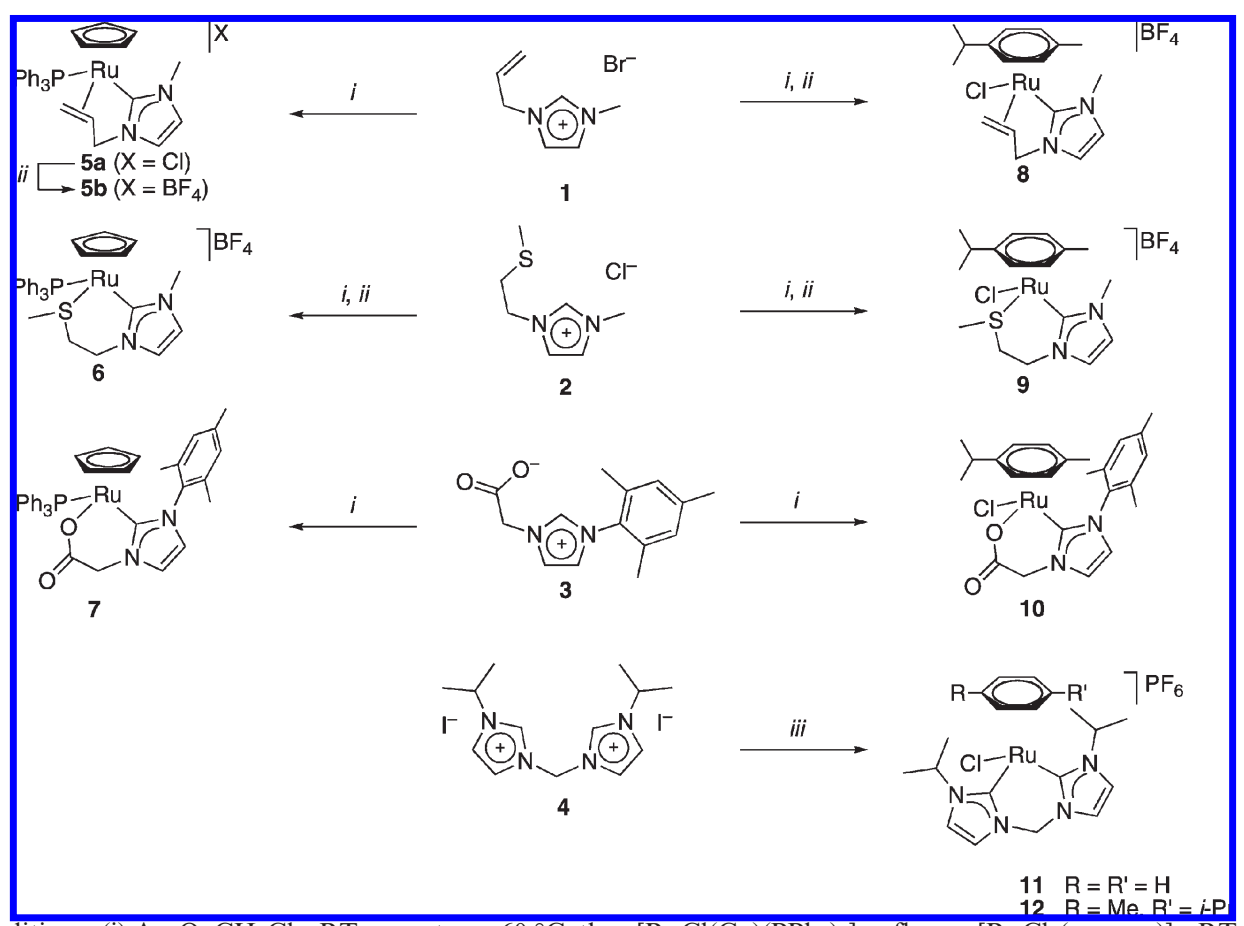

${ }^{a}$ Reagents and conditions: (i) $\mathrm{Ag}_{2} \mathrm{O}, \mathrm{CH}_{2} \mathrm{Cl}_{2}$, RT or acetone, $60^{\circ} \mathrm{C}$; then $\left[\mathrm{RuCl}(\mathrm{Cp})\left(\mathrm{PPh}_{3}\right)_{2}\right]$, reflux or $\left[\mathrm{RuCl}_{2}\left(\mathrm{cymene}_{2}\right]_{2}, \mathrm{RT}\right.$. (ii) $\mathrm{KBF}$. (iii) $\mathrm{Ag}_{2} \mathrm{O}$, $\mathrm{NH}_{4} \mathrm{PF}_{6}, \mathrm{H}_{2} \mathrm{O}, \mathrm{RT}$; then $\left[\mathrm{RuCl}_{2} \text { (cymene) }\right]_{2}$ or $\left[\mathrm{RuCl}_{2} \text { (benzene) }\right]_{2}, \mathrm{CH}_{2} \mathrm{Cl}_{2}, \mathrm{RT}$.

system are particularly pronounced in processes involving sufficiently stable intermediates that comprise metal-bound hydride, ${ }^{10,11}$ alkyl, ${ }^{12}$ or aryl groups. ${ }^{13}$

A potential strategy ${ }^{14}$ to avoid such ligand elimination and to provide access to robust catalytic entities consists of using chelation in order to stabilize the $\mathrm{M}-\mathrm{C}_{\mathrm{NHC}}$ bond. $^{15}$ In addition, chelating groups may be hemilabile, thus transiently generating vacant coordination sites for substrate

(12) For selected examples, see: (a) McGuinness, D. S.; Green, M. J.; Cavell, K. J.; Skelton, B. W.; White, A. H. J. Organomet. Chem. 1998, 565, 165. (b) McGuinness, D. S.; Cavell, K. J. Organometallics 2000, 19, 4918. (c) McGuinness, D. S.; Saendig, N.; Yates, B. F.; Cavell, K. J. J. Am. Chem. Soc. 2001, 123, 4029. (d) Magill, A. M.; McGuinness, D. S.; Cavell, K. J.; Britovsek, G. J. P.; Gibson, V. C.; White, A. J. P.; Williams, D. J.; White, A. H.; Skelton, B. W. J. Organomet. Chem. 2001, 617-618, 546. (e) Normand, A. T.; Yen, S. K.; Huynh, H. V.; Hor, T. S. A.; Cavell, K. J. Organometallics 2008, $27,3153$.

(13) McGuinness, D. S.; Cavell, K. J.; Skelton, B. W.; White, A. H. Organometallics 1999, 18, 1596 .

(14) For other approaches, see: (a) Douthwaite, R. E.; Green, M. L. H.; Silcock, P. J.; Gomesc, P. T. J. Chem. Soc., Dalton Trans. 2002, 1386. (b) Graham, D. C.; Cavell, K. J.; Yates, B. F. Dalton Trans. 2006, 1768. (c) Burling, S.; Paine, B. M.; Nama, D.; Brown, V. S.; Mahon, M.; F. Prior, T. J.; Pregosin, P. S.; Whittlesey, M. K.; Williams, J. M. J. J. Am. Chem. Soc. 2007, 129, 1987. (d) Moser, M.; Wucher, B.; Kunz, D.; Rominger, F. Organometallics 2007, 26, 1024 .

(15) For selected reviews on $\mathrm{M}-\mathrm{C}$ bonds stabilized by chelating groups, see: (a) Dehand, J.; Pfeffer, M. Coord. Chem. Rev. 1976, 18, 327. (b) Deeming, A. J.; Rothwell, I. P. Pure Appl. Chem. 1980, 52, 649. (c) Evans, D. W.; Baker, G. R.; Newkome, G. R. Coord. Chem. Rev. 1989, 93, 155. (d) Ryabov, A. D. Chem. Rev. 1990, 90, 403. (e) Dupont, J.; Pfeffer, M.; Spencer, J. Eur. J. Inorg. Chem. 2001, 1917. (f) Albrecht, M.; van Koten, G. Angew. Chem., Int. Ed. 2001, 40, 3750. (g) van der Boom, M. E.; Milstein, D. Chem. Rev. 2003, 103, 1759. (h) Singleton, J. T. Tetrahedron 2003, 59, 1837. (i) Dunina, V. V.; Gorunova, O. N. Russ. Chem. Rev. 2004, 73, 309. (j) Selander, N.; Szabo, K. J. Dalton Trans. 2009, in press. (k) Djukic, J.-P.; Sortais, J.-B.; Barloy, L.; Pfeffer, M. Eur. J. Inorg. Chem. 2009, 817-853.

(16) For reviews on chelating NHC ligands, see: (a) Peris, E.; Crabtree, R. H. Coord. Chem. Rev. 2004, 248, 2239. (b) Kuhl, O. Chem. Soc. Rev. 2007, 36, 592. (c) Liddle, S. T.; Edworthy, I. S.; Arnold, P. L. Chem. Soc. Rev. 2007, 36, 1732. (d) Albrecht, M. Chem. Commun. 2008 , 3601. (e) Normand, A. T.; Cavell, K. J. Eur. J. Inorg. Chem. 2008, 2781. binding. While chelating NHC complexes are widely known, ${ }^{16}$ they have not been used for homogeneous hydrogenation. Here we report on our efforts in using chelation ${ }^{17}$ as an effective concept to prevent the notorious elimination of the NHC ligand from the metal coordination sphere in hydrogenation catalysis. Specifically, we have developed the first NHC ruthenium(II) complex that is, according to various mechanistic analyses, robust under strongly reducing conditions $\left(60\right.$ bar $\mathrm{H}_{2}$ ). This complex hence serves as a useful catalyst precursor for homogeneous olefin hydrogenation. Optimization of the activity of such systems may provide robust, highly active, and potentially reusable catalysts.

\section{Results and Discussion}

Synthesis. The NHC ruthenium(II) complexes 5-12 were prepared by transmetalation from the corresponding silver carbene complexes (Scheme 1) following established procedures. ${ }^{18}$ Thus, reaction of the imidazolium salts $\mathbf{1 - 4}$ with a slight excess of $\mathrm{Ag}_{2} \mathrm{O}$ afforded the silver carbenes quantitatively

(17) For chelating NHC complexes relevant to this work, see: (a) Herrmann, W. A.; Elison, M.; Fischer, J.; Köcher, C.; Artus, G. R. J. Angew. Chem., Int. Ed. 1995, 34, 2371. (b) Muehlhofer, M.; Strassner, T.; Herrmann, W. A. Angew. Chem., Int. Ed. 2002, 41, 1745. (c) Geldbach, T. J.; Laurenczy, G.; Scopelliti, R.; Dyson, P. J. Organometallics 2006, 25, 733. (d) Poyatos, M.; Maisse-Francois, A.; Bellemin-Laponnaz, S.; Gade, L. H. Organometallics 2006, 25, 2634. (e) Huynh, H. V.; Yeo, C. H.; Tan, G. K. Chem. Commun. 2006, 3833. (f) Heckenroth, M.; Kluser, E.; Neels, A.; Albrecht, M. Angew. Chem., Int. Ed. 2007, 46, 6293-6296. (g) Corberan, R.; Sanau, M.; Peris, E. Organometallics 2007, 26, 3492. (h) Fliedel, C.; Schnee, G.; Braunstein, P. Dalton Trans. 2009, 2474.

(18) (a) Wang, H. M. J.; Lin, I. J. B. Organometallics 1998, 17, 972. (b) Chianese, A. R.; Li, X.; Janzen, M. C.; Faller, J. W.; Crabtree, R. H. Organometallics 2003, 22, 1663. (c) Arnold, P. L.; Scarisbrick, A. C. Organometallics 2004, 23, 2519. (d) Poyatos, M.; Maisse-François, A.; Bellemin-Laponnaz, S.; Peris, E.; Gade, L. H. J. Organomet. Chem. 2006, 691, 2713. (e) Mathew, P.; Neels, A.; Albrecht, M. J. Am. Chem. Soc. 2008 , $130,13534$. 


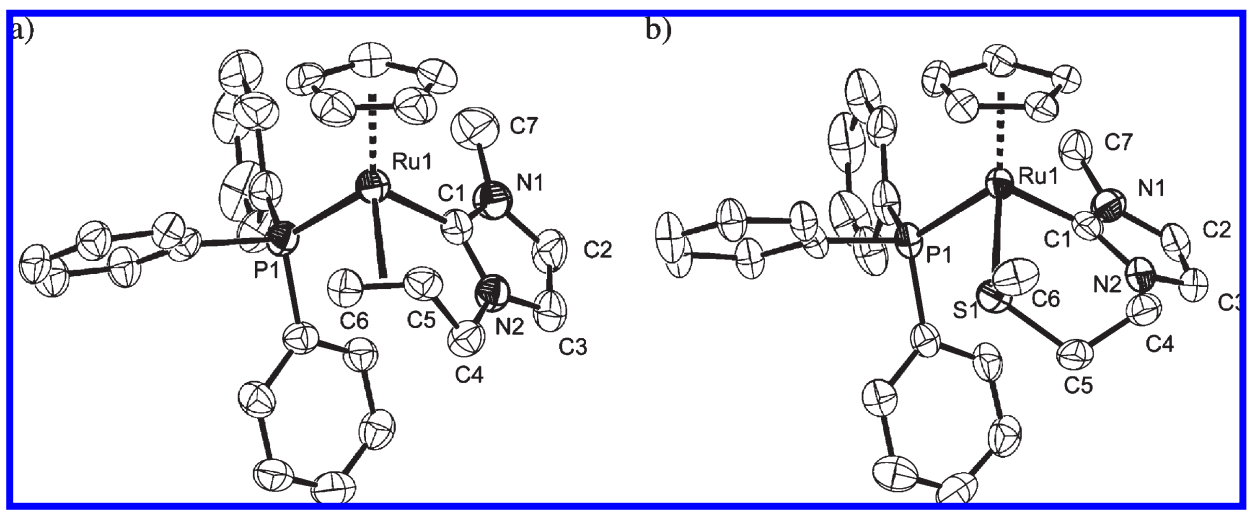

Figure 1. ORTEP representations of the cations of $\mathbf{5 a}$ (a, 50\% probability ellipsoids, only one of the two independent residues shown) and of 6 (b, 30\% probability ellipsoids; for clarity, hydrogen atoms, cocrystallized solvent molecules, and the noncoordinating anions were omitted in both structures). Selected bond lengths (A) for 5a: Ru1-C1 2.047(7), Ru1-C $\mathrm{Cp}_{\mathrm{C}}$ (centroid) 1.898(4), Ru1-P1 2.297(2), $\mathrm{Ru} 1-\mathrm{C}_{\text {olefin }}$ (centroid) 2.101(5), C6-C5 1.374(11), C5-C4 1.508(11), C2-C3 1.348(11). Selected bond angles (deg): P1-Ru1-C1 88.5(2), $\mathrm{C}_{\text {olefin }}\left(\right.$ centroid)-Ru1-C1 89.4(2), $\mathrm{C}_{\text {olefin }}$ (centroid)-Ru1-P1 94.29(14). The bond lengths and angles for the second molecule of $\mathbf{5 a}$ in the asymmetric unit are identical within esd's. Selected bond lengths ( $⿱$ A) for 6: Ru1-C1 2.052(12), Ru1- $\mathrm{C}_{\mathrm{Cp}}$ (centroid) 1.857(5), Ru1-P1 2.308(3), Ru1-S1 2.367(3), C2-C3 1.347(17). Selected bond angles (deg): P1-Ru1-C1 93.9(3), S1-Ru1-C1 90.5(3), S1Ru1-P1 84.44(8).

according to ${ }^{1} \mathrm{H}$ NMR spectroscopy. Subsequent transmetalation and, where required, exchange of the noncoordinating anion to $\mathrm{BF}_{4}^{-}$afforded complexes 5-12. The complexes were all air-stable in the solid state except for $\mathbf{7}$ and $\mathbf{8}$, which slowly decomposed, as indicated by a gradual color change from yellow to brown and from orange to dark green, respectively. Transmetalation proceeded smoothly with $\left[\mathrm{RuCl}_{2} \text { (cymene) }\right]_{2}$, and complexes 8-10 and $\mathbf{1 2}$ were obtained at RT. Higher temperatures were required for the synthesis of complexes 5-7, perhaps because displacement of a phosphine in $[\mathrm{RuCl}(\mathrm{Cp})$ $\left.\left(\mathrm{PPh}_{3}\right)_{2}\right]$ is more demanding than dimer cleavage in the cymene precursor. Attempts to form complexes 5-12 via the free carbene route ${ }^{19}$ were less successful. Imidazolium deprotonation using a strong base such as $t$-BuOK or $n$-BuLi and subsequent ruthenium coordination yielded the desired products, albeit with significant amounts of unidentified impurities.

Spectroscopic Characterization. Chelation of the potentially bidentate coordinating carbene ligands was surmised from spectroscopic measurements in solution. The ${ }^{1} \mathrm{H}$ NMR spectra generally showed an $\mathrm{AX}$ pattern for the $\mathrm{NCH}_{2}$ protons. Furthermore, the $\mathrm{C}_{\mathrm{cym}}-\mathrm{H}$ protons in complexes $\mathbf{8}-\mathbf{1 0}$ gave four distinct resonances due to chelation of the $\mathrm{NHC}$ wingtip group.

Olefin coordination to the metal center in complexes $\mathbf{5}$ and 8 was supported by the ${ }^{1} \mathrm{H}$ NMR resonances of the allyl wingtip group, which was split into five distinct signals. In $\mathbf{5 b}$ for example, the $\mathrm{NCH}_{2}$ protons appeared as two doublets of doublets $\left(\delta_{\mathrm{H}} 4.16\right.$ and $\left.1.57,{ }^{2} J_{\mathrm{HH}}=12.1 \mathrm{~Hz}\right)$ and the olefinic proton resonances were shifted to significantly higher field as compared to the signals in the ligand precursor. No dissociation of the tethered olefin group was observed when dissolving complex $\mathbf{5}$ in coordinating solvents such as $\mathrm{MeCN}$, even upon warming to $75^{\circ} \mathrm{C} .{ }^{20}$ Olefin coordination to the

(19) Baratta, W.; Herdtweck, E.; Herrmann, W. A.; Rigo, P.; Schwarz, J. Organometallics 2002, 21, 2101.

(20) In the ${ }^{1} \mathrm{H}$ NMR spectrum of complex $\mathbf{8}$, two sets of signals were observed in approximate 6:1 ratio. The small chemical shift difference of these sets suggests two closely related species. The resonances for the $\mathrm{C}_{\mathrm{cym}}-\mathrm{H}$ and in particular for the allyl wingtip and the $\mathrm{C}_{\mathrm{cym}}-\mathrm{CH}_{3}$ groups show the largest differences, whereas most other protons overlap significantly. Hence we assume the presence of two diastereoisomers that are characterized by the specific orientation of the olefin, which may coordinate either parallel or orthogonal to the $\mathrm{Cp}$ plane. ruthenium center was also evidenced by ${ }^{13} \mathrm{C}\left\{{ }^{1} \mathrm{H}\right\}$ NMR spectroscopy. The resonances due to the olefinic carbons shift from $\delta_{\mathrm{C}} 132.6$ and 121.1 in the ligand precursor to $\delta_{\mathrm{C}}$ 57.1 and 44.6 in $\mathbf{5}$ (acetone- $d_{6}$ ) and to $\delta_{\mathrm{C}} 79.3$ and 67.2 in $\mathbf{8}$ $\left(\mathrm{DMSO}-d_{6}\right)$. These high-field shifts are in line with significant $\pi$-back-bonding from the metal to the olefinic $\pi^{*}$ orbital and with a concomitant decrease of the $\mathrm{C}=\mathrm{C}$ bond order. $^{21}$

Solid State Analysis. Representative complexes were analyzed by single-crystal X-ray diffraction. The molecular structures of complexes 5a, 6, 10, and $\mathbf{1 2}$ all reveal the expected three-legged piano-stool structural motif (Figures 1 and 2). The $\mathrm{Ru}-\mathrm{C}_{\mathrm{NHC}}$ bond lengths (2.033(9)2.052(12) §) are unexceptional for ruthenium-carbene bonds. ${ }^{18,22}$ Chelation is confirmed for all donor groups, including the $\eta^{2}$-coordination mode of the olefin in $\mathbf{5 a}$ as deduced from NMR spectroscopy. The bite angles of the four different $\mathrm{NHC}$ chelates are all close to $90^{\circ}$. Moreover a short $\mathrm{C}-\mathrm{H} \cdots$ arene contact between one cymene proton and the center of the mesityl ring was noted in complex $\mathbf{1 0}$ $\left(\mathrm{C} 6-\mathrm{H} \cdots \mathrm{C}_{\text {centroid }} 2.475 \AA\right.$ A). Such edge-to-face interaction also seems to persist in solution and may account for the unusually low frequency of one of the aromatic $\mathrm{C}_{\mathrm{cym}}-\mathrm{H}$ protons in the ${ }^{1} \mathrm{H}$ NMR spectrum $\left(\delta_{\mathrm{H}} 3.34\right)$.

Electrochemistry. The electrochemical behavior of complexes 5-12 was analyzed by cyclic and differential pulse voltammetry. All complexes undergo quasi-reversible electrochemical oxidations (Table 2). ${ }^{23}$ In the Cp-containing complexes 5-7 the redox potentials correlate with the assumed donor strength of the chelating group. The oxidation

(21) (a) Godleski, S. A.; Gundlach, K. B.; Valpey, R. S. Organometallics 1985, 4, 296. (b) Hahn, C. Chem-Eur. J. 2004, 10, 5888. (c) Corberan, R.; Sanau, M.; Peris, E. Organometallics 2007, 26, 3492.

(22) Cariou, R.; Fischmeister, C.; Toupet, L.; Dixneuf, P. H. Organometallics 2006, 25, 2126.

(23) In some complexes, irreversible reduction processes were observed at negative potential, perhaps involving ligand-centered events. In addition, the redox processes are strongly dependent on the solvent. In $\mathrm{MeCN}$, the half-wave potentials were typically lower and the separation of anodic/cathodic peak potentials was narrower than in $\mathrm{CH}_{2} \mathrm{Cl}_{2}$. However, secondary processes such as ligand displacement may interfere, especially in $\eta^{6}$-arene complexes, and measurements were more reliable in $\mathrm{CH}_{2} \mathrm{Cl}_{2}$. 


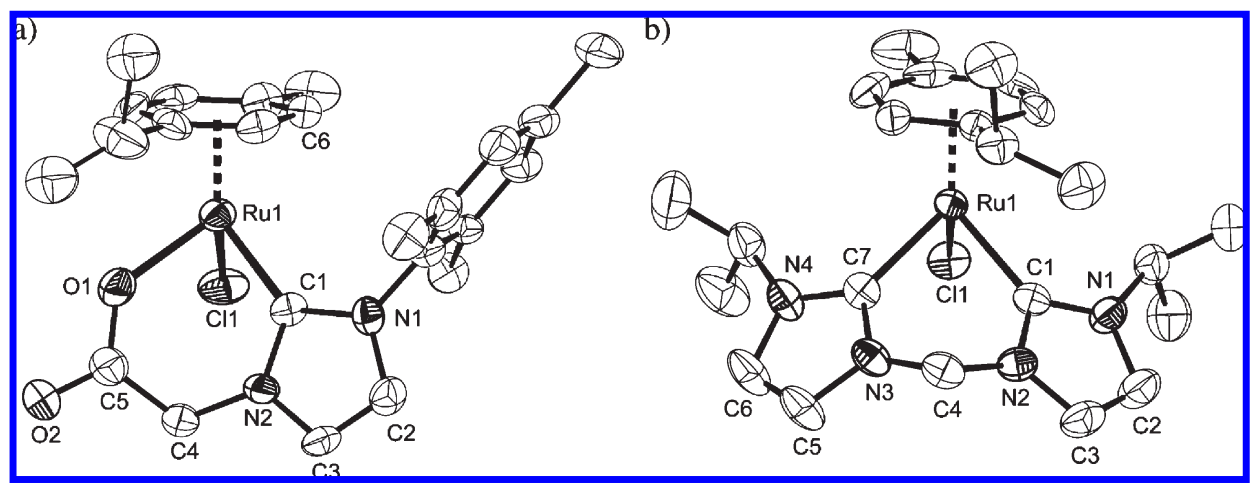

Figure 2. ORTEP representations of complexes $\mathbf{1 0}$ (a) and $\mathbf{1 2}$ (b; 50\% probability ellipsoids, hydrogen atoms, cocrystallized solvent molecules, and noncoordinating anions omitted for clarity).

Table 1. Selected Bond Lengths $(\stackrel{\AA}{)})$ and Angles $(\mathbf{d e g})$ for Complexes 10 and 12

\begin{tabular}{|c|c|c|}
\hline & 10 & 12 \\
\hline & $\mathrm{E}=\mathrm{O} 1$ & $\mathrm{E}=\mathrm{C} 7$ \\
\hline $\mathrm{Ru} 1-\mathrm{C}_{\text {centroid }}$ & $1.701(5)$ & $1.7397(15)$ \\
\hline $\mathrm{Ru} 1-\mathrm{Cl}$ & $2.033(9)$ & $2.046(3)$ \\
\hline Rul-E & $2.079(8)$ & $2.037(3)$ \\
\hline $\mathrm{Ru} 1-\mathrm{Cl} 1$ & $2.424(3)$ & $2.3912(8)$ \\
\hline $\mathrm{C} 2-\mathrm{C} 3$ & $1.321(15)$ & $1.332(5)$ \\
\hline $\mathrm{O} 1-\mathrm{C} 5$ & $1.304(13)$ & \\
\hline $\mathrm{O} 2-\mathrm{C} 5$ & $1.238(12)$ & \\
\hline $\mathrm{Cl1}-\mathrm{Ru} 1-\mathrm{Cl}$ & $83.5(3)$ & $83.94(9)$ \\
\hline E-Ru1-C1 & $86.7(3)$ & $84.39(13)$ \\
\hline E-Ru1-Cl1 & $88.5(2)$ & $84.31(9)$ \\
\hline
\end{tabular}

Table 2. Electrochemical Data of Ruthenium(II) Complexes in $\mathrm{CH}_{2} \mathrm{Cl}_{2}{ }^{a}$

\begin{tabular}{lllll}
\hline entry & complex & chelating group & $E_{1 / 2}(\mathrm{~V})$ & $\Delta E_{\mathrm{p}}(\mathrm{mV})$ \\
\hline 1 & $\mathbf{5 b}$ & olefin & 1.47 & 199 \\
2 & $\mathbf{6}$ & $\mathrm{SMe}$ & 1.03 & 132 \\
3 & $\mathbf{7}$ & $\mathrm{COO}^{-}$ & 0.48 & 84 \\
4 & $\mathbf{8}$ & olefin & 1.06 & 69 \\
5 & $\mathbf{9}$ & $\mathrm{SMe}$ & 1.55 & 174 \\
6 & $\mathbf{1 0}$ & $\mathrm{COO}^{-}$ & 1.16 & 123 \\
7 & $\mathbf{1 1}$ & $\mathrm{NHC}^{\mathrm{NHC}}$ & 1.40 & 112 \\
8 & $\mathbf{1 2}$ & $\mathrm{NHC}$ & 1.32 & 110
\end{tabular}

${ }^{a} E_{1 / 2}$ vs SCE, Pt working electrode, scan rate $100 \mathrm{mV} \mathrm{s}^{-1}$ and $0.1 \mathrm{M} n$ $\mathrm{Bu}_{4} \mathrm{NPF}_{6}$ as electrolyte. Ferrocene $\left(E_{1 / 2}=0.46 \mathrm{~V}\right)$ or $\left[\mathrm{Ru}(\mathrm{bpy})_{3}\right]\left(\mathrm{PF}_{6}\right)_{2}$ $\left(E_{1 / 2}=1.39 \mathrm{~V}\right)$ as internal standard.

potential decreases upon changing the donor from an alkene (neutral, $\pi$-acceptor) to a thioether (neutral, weak $\pi$-donor) to a carboxylate group (anionic, $\pi$-donor). ${ }^{24}$ Hence chelate tuning provides a methodology to directly control the electrochemical properties at the ruthenium center. Interestingly, the $\mathrm{PPh}_{3} / \mathrm{Cl}^{-}$donor set in the precursor complex [RuCl$\left.(\mathrm{Cp})\left(\mathrm{PPh}_{3}\right)_{2}\right]\left(E_{1 / 2}=0.59 \mathrm{~V}\right)$ is less donating than the $\mathrm{NHC} / \mathrm{COO}^{-}$set in $7\left(E_{1 / 2}=0.48 \mathrm{~V}\right)$ according to the $E_{1 / 2}$ values.

These trends are less pronounced in the cymene-containing complexes 8-10 and $\mathbf{1 2}$. Oxidation of these complexes occurred generally at higher potentials, and the functional

(24) Similar conclusions were drawn from ${ }^{31} \mathrm{P}$ NMR spectroscopy, which therefore provides another useful probe for the donor strength of the wingtip group in these complexes. The chemical shift decreases in the sequence $5\left(\mathrm{E}=\right.$ olefin, $\left.\delta_{\mathrm{P}} 59.6\right)<\mathbf{6}\left(\mathrm{E}=\right.$ thioether, $\left.\delta_{\mathrm{P}} 52.7\right)<7(\mathrm{E}=$ carboxylate, $\left.\delta_{\mathrm{P}} 49.8\right)$.
Table 3. Catalytic Hydrogenation of Styrene ${ }^{a}$

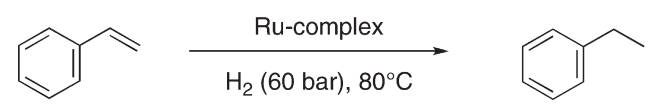

(1)

\begin{tabular}{|c|c|c|c|c|c|}
\hline & & & THF & & 1:1 \\
\hline entry & complex /loadir & time $(\mathrm{h}$ & conversion & con & TON \\
\hline 1 & $5 \mathbf{a} / 0.1 \mathrm{~mol} \%$ & 5 & 0 & 0 & 0 \\
\hline 2 & $5 \mathbf{b} / 0.1 \mathrm{~mol} \%$ & 5 & $0^{e}$ & 0 & 0 \\
\hline 3 & $6 / 0.1 \mathrm{~mol} \mathrm{\%}$ & 5 & $1^{e}$ & 3 & 30 \\
\hline 4 & $7 / 0.1 \mathrm{~mol} \%$ & 5 & 100 & 3 & 30 \\
\hline 5 & $8 / 0.1 \mathrm{~mol} \%$ & 5 & 0 & 99 & 990 \\
\hline $6^{b}$ & $8 / 1 \mathrm{~mol} \%$ & 24 & n.d. & 16 & 16 \\
\hline 7 & $9 / 0.1 \mathrm{~mol} \%$ & 5 & 0 & 14 & 140 \\
\hline 8 & $\mathbf{1 0} / 0.1 \mathrm{~mol} \%$ & 5 & $0^{e}$ & 99 & 990 \\
\hline $9^{c}$ & $\mathbf{1 0} / 0.1 \mathrm{~mol} \%$ & $5+5$ & n.d. & 84 & 1680 \\
\hline 10 & $\mathbf{1 0} / 0.01 \mathrm{~mol} \%$ & 5 & n.d. & 14 & 1400 \\
\hline $11^{d}$ & $10 / 0.1 \mathrm{~mol} \%$ & 5 & n.d. & 95 & 950 \\
\hline 12 & $11 / 0.1 \mathrm{~mol} \%$ & 5 & 10 & 8 & 80 \\
\hline
\end{tabular}

${ }^{a}$ General reaction conditions: styrene $(15 \mathrm{mmol})$, THF or THF/ EtOH 1:1, $80{ }^{\circ} \mathrm{C}, \mathrm{H}_{2}$ (60 bar), conversions were determined by ${ }^{1} \mathrm{H}$ NMR spectroscopy using $n$-octane as internal standard; n.d. $=$ not determined. ${ }^{b}$ Reaction at 1 bar $\mathrm{H}_{2} .{ }^{c}$ A new batch of styrene was added to the reaction mixture after conversion of the first batch. ${ }^{d} \mathrm{Hg}^{0}(1.3 \mathrm{~g}$, ca. 3000 molar equiv per $\mathrm{Ru}$ ) was added prior to heating and pressurizing the reaction mixture. ${ }^{e}$ Polystyrene observed as product.

group bound to the NHC ligand exerts a smaller influence on the redox potential as compared to complexes 5-7. Again, the formally neutral ruthenium center in $\mathbf{1 0}$ is oxidized at a lower potential than the cationic centers. ${ }^{25}$

Catalytic Hydrogenation. The catalytic activity of complexes 5-11 in olefin hydrogenation was evaluated using styrene as model substrate. At $80{ }^{\circ} \mathrm{C}$ under $\mathrm{H}_{2}$ pressure (60 bar) and $0.1 \mathrm{~mol} \%$ catalyst loading, moderate conversions were observed for complexes 7 and 10, containing carboxylate wingtip groups, and for complex $\mathbf{8}$, featuring an olefin-NHC ligand (Table 3 ). In contrast, complex $\mathbf{5}$, the thioether-functionalized NHC complexes $\mathbf{6}$ and $\mathbf{9}$, and the dicarbene complex $\mathbf{1 1}$ were essentially inactive. The choice of

(25) The remarkably low oxidation potential measured for complex 8 $\left(E_{1 / 2}=+1.06 \mathrm{~V}\right)$ containing a neutral $\pi$-acceptor group may arise from a dismutation reaction due to olefin decoordination, thus leading to the formation of a dicationic $\mathrm{Ru}$ (solvento) ${ }_{2} \mathrm{NHC}$ species and a neutral dichloro carbene ruthenium complex $\left[\mathrm{RuCl}_{2}(\mathrm{NHC})\right.$ (cymene)]. Such neutral complexes were reported to have related redox potentials $\left(E_{1 / 2}=+1.09\right.$ V); see: Mercs, L.; Neels, A.; Albrecht, M. Dalton Trans. 2008, 5570 . 
solvent was critically influencing the catalytic activity. Complete conversions were achieved when using complex 7 in pure THF, whereas with EtOH as cosolvent, the hydrogenation was inhibited. When using complex $\mathbf{8}$ or $\mathbf{1 0}$, however, high conversions were reached only in $\mathrm{THF} / \mathrm{EtOH}$ solvent mixtures. Initial turnover frequencies were higher for the olefin complex $\mathbf{8}$ as compared to the carboxylate complex $\mathbf{1 0}$, as reflected by the conversions after $1 \mathrm{~h}(37 \%$ and $5 \%$, respectively). Attempts to improve the initial activity of complex $\mathbf{1 0}$ have been unsuccessful thus far. For example, in an effort to create a readily accessible coordination site, complex 10 was reacted with $\mathrm{AgBF}_{4}$, thus substituting the metal-bound chloride by a weakly bound solvent molecule. This catalyst precursor gave virtually identical conversions $(97 \%$ after $5 \mathrm{~h})$, and the initial activity was not substantially altered $(8 \%$ after $1 \mathrm{~h})$. The catalytic performance of $\mathbf{8}$ improved slightly upon increasing the polar solvent fraction to pure EtOH (49\% conversion after $1 \mathrm{~h})$. Notably complex 8 is active even at atmospheric $\mathrm{H}_{2}$ pressure, albeit at higher catalyst loading (entry 6), while the carboxylate complexes $\mathbf{7}$ and $\mathbf{1 0}$ gave no hydrogenated products under these conditions. Similarly, no conversions were observed when catalysis was performed at lower temperature $\left(50{ }^{\circ} \mathrm{C}\right.$ in THF, 60 bar). Therefore high pressure and temperature is required for these complexes to be catalytically active. Reduced activity was observed with $\mathbf{1 0}$ upon lowering the catalyst loading to $0.01 \mathrm{~mol} \%$ (entry 10 ).

Different mechanisms for $\mathbf{8}$ and $\mathbf{1 0}$ were indicated by the formation of a black residue after catalytic runs with $\mathbf{8}$, while reaction mixtures using $\mathbf{1 0}$ preserved a clear appearance. This macroscopic observation was further substantiated by hydrogenations using complex $\mathbf{1 0}$ in the presence of a large excess of mercury( 0$)$. Under these conditions, styrene hydrogenation was not significantly affected (Table 3 , entry 11), thus pointing to a homogeneous mode of action. ${ }^{26}$ The robustness of the active species derived from $\mathbf{1 0}$ was further confirmed by results from addition of a second batch of substrate to the reaction mixture after $5 \mathrm{~h}$, viz., after complete consumption of the first batch. The catalytic activity was preserved and the second portion of styrene was converted to ethylbenzene in similar rates as the first one (Table 3, entry 9).

The catalytic activity of complexes $\mathbf{7}$ and $\mathbf{1 0}$ may be induced by the presence of a carboxylate donor group on the NHC ligand. ${ }^{27}$ Besides being a strong donor and thus promoting $\mathrm{H}_{2}$ oxidative addition at the ruthenium center, the carboxylate functionality may induce the heterolytic cleavage of dihydrogen across the $\mathrm{Ru}-\mathrm{O}$ bond, ${ }^{28}$ a pathway that is excluded with systems such as 8. Heterolytic $\mathrm{H}-\mathrm{H}$ bond scission is particularly useful for the hydrogenation of polar double bonds. We have therefore probed the activity of $\mathbf{1 0}$ as catalyst precursor for the direct hydrogenation of

(26) (a) Anton, D. R.; Crabtree, R. H. Organometallics 1983, $2,855$. (b) Widegren, J. A.; Finke, R. G. J. Mol. Catal. A 2003, 198, 317.

(27) Enhanced catalytic activity due to the presence of a carboxylate group has been reported: (a) Sanchez-Delgado, R. A.; Valencia, N.; Marquez-Silva, R.-L.; Andriollo, A.; Medina, M. Inorg. Chem. 1986, 25, 1106. (b) Halbach, T. S.; Mix, S.; Fischer, D.; Maechling, S.; Krause, J. O.; Sievers, C.; Blechert, S.; Nuyken, O.; Buchmeiser, M. R. J. Org. Chem. 2005, 70, 4687. (c) Samec, J. S. M.; Grubbs, R. H. Chem-Eur. J. 2008, 14 , 2686.

(28) (a) Ashby, M. T.; Halpern, J. J. Am. Chem. Soc. 1991, 113, 589. (b) Chu, H. S.; Lau, C. P.; Wong, K. Y.; Wong, W. T. Organometallics 1998 , 17, 2768. (c) Noyori, R.; Ohkuma, T. Angew. Chem., Int. Ed. 2001, 40, 40. (d) Chaplin, A. B.; Dyson, P. J. Inorg. Chem. 2008, 47, 381.

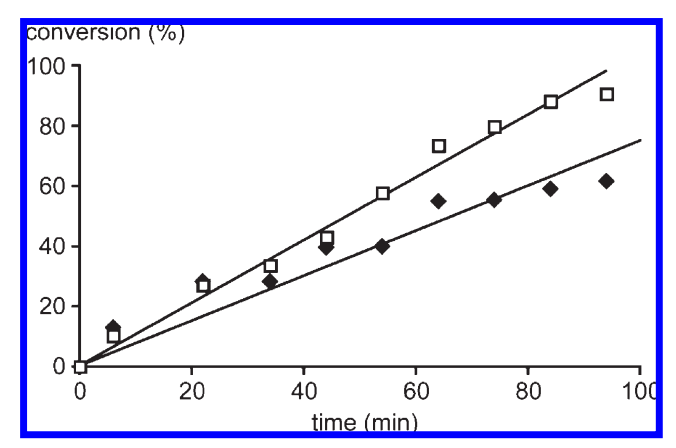

Figure 3. Time-dependent formation of ethylbenzene ( $\square$ ) and the imidazolium cation $(\diamond)$ monitored by high-pressure ${ }^{1}$ H NMR spectroscopy (styrene/complex 8, 20:1).

ketones and imines. Under conditions identical to those used for styrene hydrogenation, benzophenone was converted to the corresponding alcohol in $32 \%$ yield after $5 \mathrm{~h}$, and benzylidenemethylamine was not affected at all. On the basis of these results, homolytic dihydrogen activation seems to prevail and heterolytic carboxylate-assisted $\mathrm{H}_{2}$ cleavage appears rather unlikely.

Mechanistic Aspects. Preliminary NMR investigations of hydrogenation runs using $\mathbf{8}$ as catalyst precursor indicated the rapid formation of a $N$-methyl- $N^{\prime}$-propylimidazolium salt, suggesting that hydrogenation of the coordinated olefin moiety is fast. For example, after $15 \mathrm{~min}$ the styrene conversion reached $4 \%$ (TON 40), yet the imidazolium salt was formed in quantitative amounts according to NMR integration of the pertinent signals in the aromatic region. ${ }^{29}$ Accordingly, significant amounts of styrene are converted only after dissociation of the chelating NHC ligand from the ruthenium coordination sphere. In addition several multiplets were resolved in the hydridic high-field region $\left(-10>\delta_{\mathrm{H}}>-20\right)$, pointing to the formation of various (poly)hydride ruthenium species. In contrast precatalyst $\mathbf{1 0}$ appeared to be more stable and was recovered by precipitation with pentane in $23 \%$ yield after $5 \mathrm{~h}$ styrene hydrogenation.

Stimulated by these preliminary observations we further investigated the catalytic reaction by in situ high-pressure NMR spectroscopy using sapphire NMR tubes. Reactions were performed under slightly modified conditions $\left(70{ }^{\circ} \mathrm{C}\right.$, 100 bar $\mathrm{H}_{2}$ ) and using an increased catalyst/substrate ratio $(1: 20)$ in order to monitor the signals due to the catalyst precursor.

When using complex 8 , the resonance at $\delta_{\mathrm{H}} 5.78$ attributed to a proton of the coordinated olefin disappeared within a few minutes. Simultaneously the four doublets of the bound cymene merge to a single resonance located at $\delta_{\mathrm{H}} 7.05 \mathrm{ppm}$, diagnostic for the formation of free cymene. Hence, complex 8, comprising an olefin-tethered NHC ligand, is not stable under hydrogenation conditions, and the olefin wingtip group is hydrogenated at an early stage of the reaction. While this intramolecular olefin hydrogenation may generate a coordinatively unsaturated species as active catalyst, it also transforms the NHC into a monodentate ligand, which becomes unstable. Especially in the presence of metal-bound

(29) The appearance of three new signals in the aromatic region $\left(\delta_{\mathrm{H}}\right.$ $9.04,7.77$, and $7.72 ; d_{6}$-acetone) was attributed to the formation of the imidazolium salt. These shifts compare well with those of an authentic sample of $N$-methyl- $N^{\prime}$-propylimidazolium comprising a bromide anion. 
Scheme 2. Proposed Ligand Dissociation Pathway from Complex 8

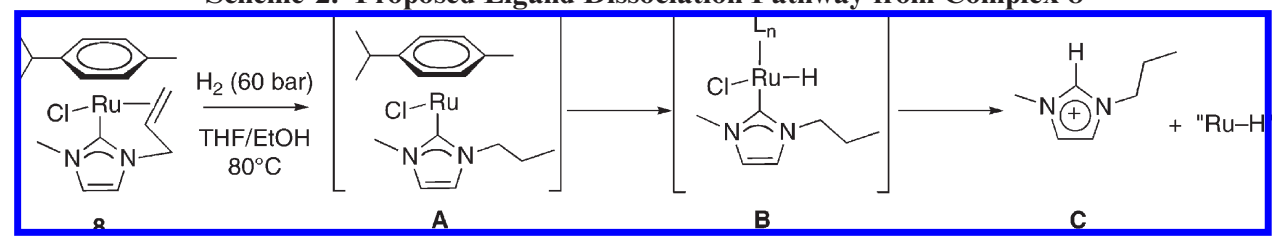

hydrides, gradual reductive elimination of the imidazolium salt takes place (Scheme 2). ${ }^{10}$ Formation of the imidazolium cation and styrene hydrogenation occurred at similar rates (Figure 3). After 1 h, 64\% styrene was converted and the free imidazolium cation $\mathbf{C}$ was formed in $48 \%$ yield (Scheme 2). After $1.5 \mathrm{~h}$, all styrene was consumed and the signal due to the free imidazolium species raised to $60 \%$. On the basis of these observations, the carbene ligand in complex $\mathbf{8}$ seems to be only a leaving group and, hence, inappropriate to influence the catalyst activity or selectivity. Complex decomposition and formation of a metastable catalytically active species is corroborated by the appearance of a black solid at the end of runs using complex $\mathbf{8}$.

Further insight in the limited stability of complex $\mathbf{8}$ under catalytically relevant conditions was obtained from studies in the absence of an olefin substrate. Complete cymene decoordination and hydrogenation of the allyl wingtip group was noted within 25 min. ${ }^{30}$ Concomitantly, the heterocyclic protons attached to $\mathrm{C} 4$ and $\mathrm{C} 5\left(\delta_{\mathrm{H}} 7.32\right.$ and 7.28) disappeared, yet the new set of signals belonging to the hydrogenated imidazolium cation appeared only within approximately $90 \mathrm{~min}$. Notably, the rate of imidazolium salt formation is essentially identical in the absence and presence of styrene. This similarity suggests that reductive NHC elimination is, under high $\mathrm{H}_{2}$ pressure, substrate-independent. The different rates observed for the disappearance of complex $\mathbf{8}$ and the appearance of the imidazolium salt may be due to the formation of an intermediate species comprising a Ru-NHC fragment that lacks a cymene spectator ligand (B, Scheme 2) prior to reductive NHC elimination. In such a species the NMR signals of the NHC ligand are expected to be shifted and may overlap with other resonances.

High-pressure NMR spectroscopic monitoring of catalytic runs using the carboxylate complex $\mathbf{1 0}$ under identical conditions to those applied for $\mathbf{8}$ revealed a substantially higher stability of complex $\mathbf{1 0}$. Integration of the cymene protons indicated that at $100 \%$ conversion (140 $\mathrm{min}$ ) the concentration of complex $\mathbf{1 0}$ decreased only to $85 \%$ (Figure 4). A new set of signals, tentatively attributed to the free imidazolium cation, appeared at $\delta_{\mathrm{H}} 9.34,7.95$, and 7.68. According to the integrals of these signals, the imidazolium salt corresponds to $12 \%$ of the initial catalyst precursor (cf. almost quantitative imidazolium formation from 8 after $140 \mathrm{~min}$ ). No induction time was observed when using such high catalyst loadings. In combination with the results from the mercury experiment (cf. Table 3, entry 11), small amounts of colloidal ruthenium particles may confidently be excluded as active species for the heterogeneous hydrogenation.

Exposure of complex $\mathbf{1 0}$ to 100 bar $\mathrm{H}_{2}$ in the absence of styrene confirmed the robustness of this complex in a strongly reducing environment. The stability of complex $\mathbf{1 0}$ was slightly decreased without styrene, as indicated by

(30) See the Supporting Information for further details.

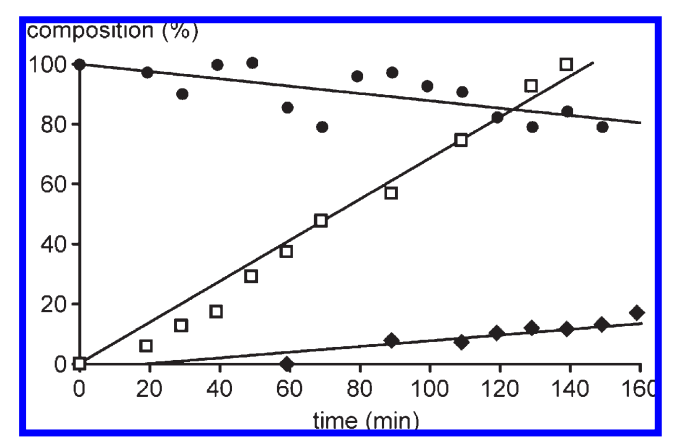

Figure 4. Time-dependent evolution of ethylbenzene ( $\square$ ) and imidazolium salt $(\$)$ and disappearance of complex $10(\bullet)$ monitored by high-pressure ${ }^{1} \mathrm{H}$ NMR spectroscopy (styrene/ complex 10, 20:1).

Table 4. Rates for the Decomposition of Complex 10 and Imidazolium Formation $^{a}$

\begin{tabular}{llll}
\hline entry & \multicolumn{1}{c}{ process } & \multicolumn{1}{c}{ conditions } & rate $\left(\mathrm{mM} \mathrm{h}^{-1}\right)$ \\
\hline 1 & imidazolium formation & with styrene & 0.284 \\
2 & imidazolium formation & without styrene & 0.153 \\
3 & precatalyst decomposition & with styrene & 0.369 \\
4 & precatalyst decomposition & without styrene & 0.684
\end{tabular}

${ }^{a}$ Determined by NMR integration, $5.0 \mathrm{mM}$ initial complex concentration.

the $\sim 25 \%$ decomposition after 140 min (cf. $\sim 15 \%$ in the presence of styrene; Table 4). Complete formation of the imidazolium salt required more than $10 \mathrm{~h}$ of exposure. Interestingly, the low-field doublet due to the $\mathrm{NCH}_{2} \mathrm{COO}^{-}$ protons $\left(\delta_{\mathrm{H}} 4.83,{ }^{2} J_{\mathrm{HH}}=15.8 \mathrm{~Hz}\right)^{31}$ was persistent, revealing that the $\mathrm{COO}^{-}$moiety was not hydrogenated. The enhanced stability of complex $\mathbf{1 0}$ under reducing conditions is further supported by the fact that after $5 \mathrm{~h}$ of catalysis the active species is preserved and a second batch of substrate is converted again with good yields (cf. Table 3, entry 9). Accordingly, this catalyst precursor may be efficiently recycled and reused.

The stabilizing effect of styrene suggests that the hydride transfer from ruthenium to the olefin substrate is competitive with hydride transfer to the NHC ligand in complex 10. On the basis of this model, reductive elimination is slower with higher substrate/catalyst ratios. In the NMR experiments, the hydride transfer from ruthenium to the NHC ligand is at least 10 times slower than the transfer to styrene, cf. the 20:1 styrene/catalyst ratio at the reaction onset and the rates of ethylbenzene $\left(41.9 \mathrm{mM} \mathrm{h}^{-1}\right)$ and imidazolium formation $\left(0.284 \mathrm{mM} \mathrm{h}^{-1}\right)$. At a more relevant styrene/catalyst ratio of 1000:1, the transfer to styrene is even more favored and leads to a degree of catalyst stability that is sufficiently high for

(31) The high-field part of the AX signal was covered by solvent resonances. 
Table 5. Polystyrene Formation with Ruthenium Carbene Complexes $^{a}$

\begin{tabular}{lccc}
\hline complex & $M_{\mathrm{w}}$ & $M_{\mathrm{w}} / M_{\mathrm{n}}$ & conversion $^{b}$ \\
\hline $\mathbf{5 b}$ & 51845 & 1.221 & $9 \%$ \\
$\mathbf{6}$ & 14519 & 1.250 & $24 \%$ \\
$\mathbf{1 0}$ & 125955 & 1.321 & $30 \%$ \\
\multicolumn{2}{c}{${ }^{a}$ Conditions: as in Table 3. ${ }^{b}$ Determined by NMR integration of the } \\
signal.
\end{tabular}

employing complex $\mathbf{1 0}$ in multiple catalytic runs (cf. Table 3, entry 9).

Polymerization under Hydrogenation Condition. With some of the ruthenium complexes, polystyrene rather than ethylbenzene formation was observed during hydrogenation experiments. Specifically, complexes 5, 6, and $\mathbf{1 0}$ gave, according to NMR analysis of crude reaction mixtures, $10-30 \%$ polymeric material in THF solution (Table 5). Product analysis by GPC revealed a relatively narrow polydispersity of $\sim 1.3$, indicating a moderately controlled polymerization. Given the activity of related complexes in ATRP, ${ }^{32}$ a similar process may operate with the complexes reported here.

Notably, under atmospheric $\mathrm{H}_{2}$ pressure or in air, no polymerization was observed. Obviously high $\mathrm{H}_{2}$ pressure is required in order to activate the catalyst also for polymerization. Similarly, EtOH seems to poison the active species, since polymerization was only observed when reactions were carried out in THF. Hence the activity of complex $\mathbf{1 0}$ can be swapped from styrene polymerization to hydrogenation by adding EtOH to pure THF. In contrast, complex $\mathbf{8}$ is a hydrogenation catalyst only, while $\mathbf{5}$ is active in polymerization exclusively.

\section{Conclusions}

A series of new ruthenium complexes comprising bidentate NHC ligands were prepared, and their electrochemical properties and catalytic hydrogenation efficiency were investigated. The donor properties of the chelating wingtip group allow for tailoring the redox potential of the rutheniuim(II) center.

Some of the chelate complexes were active catalyst precursors for the direct hydrogenation of styrene. The highest activity was found with neutral complexes comprising a carboxylate wingtip group. Electrochemical studies revealed that the tethered carboxylate donor raises the electron density at ruthenium. According to mechanistic studies using high-pressure in situ NMR spectroscopy, the carboxylate group also prevents the NHC from being reductively eliminated. Both aspects may be relevant for the catalytic $\mathrm{H}_{2}$ activation. Notably, these complexes represent the first NHC ruthenium complexes that are stable in a strongly reducing environment. The catalytic activity paired with the large potential for further optimization, for example through chelate modifications and through substitution of ancillary ligands, makes these bidentate NHC ruthenium complexes attractive systems for further exploitation in hydrogenation.

(32) Delaude, L.; Delfosse, S.; Richel, A.; Demonceau, A.; Noels, A. F. Chem. Commun. 2003, 1526.

\section{Experimental Section}

General Procedures. Syntheses involving transition metals were carried out under argon using standard Schlenk techniques. Pentane, $\mathrm{CH}_{2} \mathrm{Cl}_{2}, \mathrm{Et}_{2} \mathrm{O}, \mathrm{MeCN}$, and THF were dried by passage through solvent purification columns. The imidazolium salts $1,{ }^{33} \mathbf{3}^{34} \mathbf{4},{ }^{35}$ and $\left[\mathrm{RuCl}(\mathrm{Cp})\left(\mathrm{PPh}_{3}\right)_{2}\right]^{36}$ were reported previously. All other reagents are commercially available and were used as received. Flash chromatography was performed on silica gel 60 (63-200 mesh).

All ${ }^{1} \mathrm{H},{ }^{13} \mathrm{C}\left\{{ }^{1} \mathrm{H}\right\}$, and ${ }^{31} \mathrm{P}$ NMR spectra were recorded at $25^{\circ} \mathrm{C}$ on Bruker spectrometers and referenced to residual solvent ${ }^{1} \mathrm{H}$ or ${ }^{13} \mathrm{C}$ resonances or external $\mathrm{H}_{3} \mathrm{PO}_{4}(\delta$ in ppm, $J$ in $\mathrm{Hz})$. Assignments are based on either distortionless enhancement of polarization transfer (DEPT) experiments, nuclear Overhauser effects, or homo- and heteronuclear shift correlation spectroscopy. IR spectra were recorded on a Mattson 5000 FTIR spectrometer. Mass spectra were measured by electrospray ionization (ESI-MS, positive mode) on a Bruker Daltonics esquire HCT instruments. Elemental analyses were performed by the Microanalytical Laboratory of Ilse Beetz (Kronach, Germany) and at the ETH Zürich (Switzerland). Residual solvents were identified by ${ }^{1} \mathrm{H}$ NMR spectroscopy.

Electrochemical studies were carried out using an EG\&G Princeton Applied Research potentiostat model 273A employing a gastight three-electrode cell under an argon atmosphere. A silver/silver chloride electrode was used as reference and a Pt disk $\left(3.8 \mathrm{~mm}^{2}\right)$ and a Pt wire were used as the working and counter electrode, respectively. Redox potentials were measured in dry $\mathrm{CH}_{2} \mathrm{Cl}_{2}(\sim 1 \mathrm{mM})$ with $n-\mathrm{Bu}_{4} \mathrm{NPF}_{6}(0.1 \mathrm{M})$ as supporting electrolyte and ferrocene $\left(E_{1 / 2}=0.46 \mathrm{~V} \text { vs } \mathrm{SCE}\right)^{37}$ or $\left[\mathrm{Ru}(\mathrm{bpy})_{3}\right]\left[\mathrm{PF}_{6}\right]_{2}\left(E_{1 / 2}=1.39 \mathrm{~V} \text { vs SCE}\right)^{38}$ as internal standard.

Synthesis of 2. Neat 2-chloroethylmethyl sulfide $(0.68 \mathrm{~mL}$, $6.7 \mathrm{mmol})$ was added to $N$-methylimidazole $(455 \mathrm{mg}$, $5.55 \mathrm{mmol})$. The mixture was stirred at $60{ }^{\circ} \mathrm{C}$ for $20 \mathrm{~h}$. The formed oil was dissolved in $\mathrm{MeOH}(2 \mathrm{~mL})$ and added dropwise to THF $(50 \mathrm{~mL})$. The suspension was centrifuged, and the obtained residue was dried in vacuo to give a colorless viscous oil $(675 \mathrm{mg}, 63 \%)$ that was moderately hygroscopic. ${ }^{1} \mathrm{H}$ NMR $\left(\mathrm{CDCl}_{3}, 360 \mathrm{MHz}\right): \delta 10.64(\mathrm{~s}, 1 \mathrm{H}, \mathrm{NCHN}), 7.61,7.42(2 \times \mathrm{s}$, $\left.2 \mathrm{H}, \mathrm{C}_{\mathrm{imi}}-\mathrm{H}\right), 4.63\left(\mathrm{t},{ }^{3} \mathrm{~J}_{\mathrm{HH}}=6.3 \mathrm{~Hz}, 2 \mathrm{H}, \mathrm{NCH}_{2}\right), 4.06(\mathrm{~s}, 3 \mathrm{H}$, $\left.\mathrm{NCH}_{3}\right), 3.01\left(\mathrm{t},{ }^{3} J_{\mathrm{HH}}=6.3 \mathrm{~Hz}, 2 \mathrm{H}, \mathrm{SCH}_{2}\right), 2.18\left(\mathrm{~s}, 3 \mathrm{H}, \mathrm{SCH}_{3}\right)$. ${ }^{13} \mathrm{C}\left\{{ }^{1} \mathrm{H}\right\}$ NMR (CDCl $\left.3,90 \mathrm{MHz}\right): \delta 138.7(\mathrm{NCN}), 123.0,122.7$ $\left(2 \times \mathrm{C}_{\mathrm{imi}}-\mathrm{H}\right), 48.6\left(\mathrm{NCH}_{2}\right), 36.8\left(\mathrm{NCH}_{3}\right), 34.5\left(\mathrm{CH}_{2} \mathrm{~S}\right), 15.6$ $\left(\mathrm{SCH}_{3}\right)$. Anal. Calcd for $\mathrm{C}_{7} \mathrm{H}_{13} \mathrm{ClN}_{2} \mathrm{~S}(192.71) \times 1.25 \mathrm{H}_{2} \mathrm{O}: \mathrm{C}$ 39.06, H 7.26, N 13.27. Found: C 38.91, H 6.98, N 13.27.

Synthesis of Complex 5a. A solution of $\mathbf{1}(242 \mathrm{mg}, 1.17 \mathrm{mmol})$ in $\mathrm{CH}_{2} \mathrm{Cl}_{2}(40 \mathrm{~mL})$ was treated with $\mathrm{Ag}_{2} \mathrm{O}(0.14 \mathrm{~g}, 0.58 \mathrm{mmol})$. The suspension was stirred in the dark for $24 \mathrm{~h}$ and then filtered over Celite. Solid $\left[\mathrm{RuCl}(\mathrm{Cp})\left(\mathrm{PPh}_{3}\right)_{2}\right](0.51 \mathrm{~g}, 0.70 \mathrm{mmol})$ was added and the solution was stirred at reflux for $48 \mathrm{~h}$. The crude mixture was filtered over a pad of Celite and concentrated to $5 \mathrm{~mL}$. Upon slow addition of $\mathrm{Et}_{2} \mathrm{O}(60 \mathrm{~mL})$, a yellow precipitate formed, which was filtered, redissolved in $\mathrm{CH}_{2} \mathrm{Cl}_{2}(2 \mathrm{~mL})$, and precipitated with $\mathrm{Et}_{2} \mathrm{O}(10 \mathrm{~mL})$. The precipitate was redissolved in a minimum amount of $\mathrm{CHCl}_{3}$, filtered over Celite, and recrystallized from $\mathrm{CH}_{2} \mathrm{Cl}_{2} /$ pentane, thus yielding $\mathbf{5 a}$ as yellow crystals (97 mg, 24\%). ${ }^{1} \mathrm{H}$ NMR (acetone- $d_{6}, 500 \mathrm{MHz}$ ):

(33) Zhao, D.; Fei, Z.; Geldbach, T. J.; Scopelliti, R.; Laurenczy, G.; Dyson, P. J. Helv. Chim. Acta 2005, 88, 665.

(34) (a) Fei, Z.; Zhao, D.; Geldbach, T. J.; Scopelliti, R.; Dyson, P. J. Chem.-Eur. J. 2004, 10, 4886. (b) Moore, L. R.; Cooks, S. M.; Anderson, M. S.; Schanz, H.-J.; Griffin, S. T.; Rogers, R. D.; Kirk, M. C.; Shaughnessy, H. Organometallics 2006, 25, 5151 .

(35) Douthwaite, R. E.; Haussinger, D.; Green, M. L. H.; Silcock, P. J.; Gomes, P. T.; Martins, A. M.; Danopoulos, A. A. Organometallics $1999,18,4584$

(36) Bruce, M. I.; Windsor, N. J. Aust. J. Chem. 1977, 30, 1601.

(37) Connelly, N. G.; Geiger, W. E. Chem. Rev. 1996, 96, 877.

(38) Determined using the ferrocenium/ferrocene $\left(\mathrm{Fc}^{+} / \mathrm{Fc}\right)$ couple. 
$\delta 7.8-6.8(\mathrm{~m}, 15 \mathrm{H}, \mathrm{Ph}), 7.34,7.27\left(2 \times \mathrm{d},{ }^{3} J_{\mathrm{HH}}=2.0 \mathrm{~Hz}, 2 \mathrm{H}\right.$, $\left.\mathrm{C}_{\mathrm{NHC}}-\mathrm{H}\right), 5.44\left(\mathrm{~s}, 5 \mathrm{H}, \mathrm{H}_{\mathrm{Cp}}\right), 5.3\left(\mathrm{~m}, 1 \mathrm{H}, \mathrm{CH}=\mathrm{CH}_{2}\right), 4.17(\mathrm{dd}$, $\left.{ }^{2} J_{\mathrm{HH}}=12.1,{ }^{3} J_{\mathrm{HH}}=7.0 \mathrm{~Hz}, 1 \mathrm{H}, \mathrm{NCH}_{2}\right), 4.02\left(\mathrm{~d},{ }^{3} J_{\mathrm{HH}}=8.2 \mathrm{~Hz}\right.$, $\left.1 \mathrm{H}, C=\mathrm{CH}_{2}\right), 3.15\left(\mathrm{~s}, 3 \mathrm{H}, \mathrm{NCH}_{3}\right), 2.01\left(\mathrm{~m}, 1 \mathrm{H}, C=\mathrm{CH}_{2}\right), 1.53$ $\left(\mathrm{dd},{ }^{2} J_{\mathrm{HH}}=12.1,{ }^{3} J_{\mathrm{HH}}=8.3 \mathrm{~Hz}, 1 \mathrm{H}, \mathrm{NCH}_{2}\right) .{ }^{13} \mathrm{C}\left\{{ }^{1} \mathrm{H}\right\} \mathrm{NMR}$ (acetone- $\left.d_{6}, 125 \mathrm{MHz}\right): \delta 175.6\left(\mathrm{~d},{ }^{2} J_{\mathrm{CP}}=20.2 \mathrm{~Hz}, \mathrm{C}_{\mathrm{NHC}}-\mathrm{Ru}\right)$, $134.9\left(\mathrm{~d},{ }^{1} J_{\mathrm{CP}}=17.6 \mathrm{~Hz}, \mathrm{C}_{\mathrm{Ph}}-\mathrm{P}\right), 134.2\left(\mathrm{br}, \mathrm{C}_{\mathrm{Ph}}-\mathrm{H}\right), 131.4$ $\left(\mathrm{C}_{\mathrm{Ph}}-\mathrm{H}\right), 129.6\left(\mathrm{~d}, J_{\mathrm{CP}}=9.6 \mathrm{~Hz}, \mathrm{C}_{\mathrm{Ph}}-\mathrm{H}\right), 126.2,121.0(2 \times$ $\left.\mathrm{C}_{\mathrm{NHC}}\right), 87.7\left(\mathrm{C}_{\mathrm{Cp}}\right), 57.1\left(\mathrm{CH}=\mathrm{CH}_{2}\right), 51.3\left(\mathrm{NCH}_{2}\right), 44.6$ $\left(C=\mathrm{CH}_{2}\right), 37.4\left(\mathrm{NCH}_{3}\right) .{ }^{31} \mathrm{P}$ NMR (acetone- $\left.d_{6}, 162 \mathrm{MHz}\right)$ : $\delta 59.6\left(\mathrm{PPh}_{3}\right)$. Anal. Calcd for $\mathrm{C}_{30} \mathrm{H}_{30} \mathrm{ClN}_{2} \mathrm{PRu}(586.08) \times$ $\mathrm{H}_{2} \mathrm{O} \times 2 \mathrm{CH}_{2} \mathrm{Cl}_{2}: \mathrm{C} 49.66, \mathrm{H} 4.69, \mathrm{~N}$ 3.62. Found: C 49.42, $\mathrm{H} 4.42$, N 3.81 .

Synthesis of Complex 5b. A solution of $\mathbf{5 a}(97 \mathrm{mg}, 0.16 \mathrm{mmol})$ in $\mathrm{CH}_{2} \mathrm{Cl}_{2}(2 \mathrm{~mL})$ was added to a suspension of $\mathrm{KBF}_{4}(62 \mathrm{mg}$, $0.49 \mathrm{mmol})$ in acetone $(10 \mathrm{~mL})$. The mixture was stirred at RT for $2 \mathrm{~h}$. $\mathrm{Et}_{2} \mathrm{O}(40 \mathrm{~mL})$ was added, and the mixture was filtered over Celite. The supernatant was evaporated in vacuo to give $\mathbf{5 b}$ as a yellow waxy solid (74 mg, 72\%). ${ }^{1} \mathrm{H}$ NMR (acetone- $d_{6}, 400$ MHz): $\delta 7.70-6.90(\mathrm{~m}, 15 \mathrm{H}, \mathrm{Ph}), 7.32,7.27\left(2 \times \mathrm{d},{ }^{3} J_{\mathrm{HH}}=2.0\right.$ $\left.\mathrm{Hz}, 2 \mathrm{H}, \mathrm{C}_{\mathrm{NHC}}-\mathrm{H}\right), 5.42\left(\mathrm{~s}, 5 \mathrm{H}, \mathrm{H}_{\mathrm{Cp}}\right), 5.3\left(\mathrm{~m}, 1 \mathrm{H}, \mathrm{CH}=\mathrm{CH}_{2}\right)$, $4.16\left(\mathrm{dd},{ }^{2} J_{\mathrm{HH}}=12.1,{ }^{3} J_{\mathrm{HH}}=7.1 \mathrm{~Hz}, 1 \mathrm{H}, \mathrm{NCH}_{2}\right), 4.00\left(\mathrm{~d},{ }^{3} J_{\mathrm{HH}}=\right.$ $\left.8.2 \mathrm{~Hz}, 1 \mathrm{H}, C=\mathrm{CH}_{2}\right), 3.16\left(\mathrm{~s}, 3 \mathrm{H}, \mathrm{CH}_{3}\right), 2.04\left(\mathrm{~m}, 1 \mathrm{H}, C=\mathrm{CH}_{2}\right)$, $1.57\left(\mathrm{dd},{ }^{2} J_{\mathrm{HH}}=12.1,{ }^{3} J_{\mathrm{HH}}=8.4 \mathrm{~Hz}, 1 \mathrm{H}, \mathrm{NCH}_{2}\right) .{ }^{13} \mathrm{C}\left\{{ }^{1} \mathrm{H}\right\} \mathrm{NMR}$ (acetone- $\left.d_{6}, 100 \mathrm{MHz}\right): \delta 175.6\left(\mathrm{~d},{ }^{2} J_{\mathrm{CP}}=20.2 \mathrm{~Hz}, \mathrm{C}_{\mathrm{NHC}}-\mathrm{Ru}\right)$, $134.3\left(\mathrm{br}, \mathrm{C}_{\mathrm{Ph}}-\mathrm{H}\right), 131.4\left(\mathrm{C}_{\mathrm{Ph}}-\mathrm{H}\right), 129.6\left(\mathrm{~d}, J_{\mathrm{CP}}=9.7 \mathrm{~Hz}, \mathrm{C}_{\mathrm{Ph}}-\right.$ $\mathrm{H}), 126.2,121.0\left(2 \times \mathrm{C}_{\mathrm{NHC}}\right), 87.7\left(\mathrm{C}_{\mathrm{Cp}}\right), 57.1\left(\mathrm{CH}=\mathrm{CH}_{2}\right), 51.3$ $\left(\mathrm{NCH}_{2}\right), 44.6\left(C=\mathrm{CH}_{2}\right), 37.4\left(\mathrm{NCH}_{3}\right), \mathrm{C}_{\mathrm{Ph}}-\mathrm{P}$ not resolved. ${ }^{31} \mathrm{P}$ NMR (acetone- $\left.d_{6}, 162 \mathrm{MHz}\right): \delta 59.6\left(\mathrm{PPh}_{3}\right) . \mathrm{MS}(\mathrm{ESI})$ $m / z$ : $551.1\left[\mathrm{M}-\mathrm{BF}_{4}\right]^{+}$. Anal. Calcd for $\mathrm{C}_{30} \mathrm{H}_{30} \mathrm{BF}_{4} \mathrm{~N}_{2} \mathrm{PRu}$ (637.43) $\times \mathrm{CH}_{2} \mathrm{Cl}_{2}: \mathrm{C} 51.54, \mathrm{H} 4.47, \mathrm{~N} 3.88$. Found: C 51.80, $\mathrm{H} 4.67, \mathrm{~N} 3.86$.

Synthesis of Complex 6. Using a procedure identical to that for preparing $5 \mathbf{a}$, reaction of $2(0.15 \mathrm{~g}, 0.75 \mathrm{mmol})$ with $\mathrm{Ag}_{2} \mathrm{O}$ $(0.12 \mathrm{~g}, 0.49 \mathrm{mmol})$ and $\left[\mathrm{RuCl}(\mathrm{Cp})\left(\mathrm{PPh}_{3}\right)_{2}\right](0.49 \mathrm{~g}, 0.67 \mathrm{mmol})$ in $\mathrm{CH}_{2} \mathrm{Cl}_{2}(40 \mathrm{~mL})$ gave, after repetitive precipitation, a yellow residue. This residue was redissolved in THF and added to a warm suspension of $\mathrm{KBF}_{4}(0.49 \mathrm{~g}, 3.8 \mathrm{mmol})$ in THF $(60 \mathrm{~mL})$. The mixture was stirred for $12 \mathrm{~h}$ at RT and then filtered over Celite. Solvent removal in vacuo afforded $\mathbf{6}$ as a pale yellow solid (206 mg, 45\%). Crystals suitable for X-ray diffraction were grown by slow diffusion of pentane into a $\mathrm{CH}_{2} \mathrm{Cl}_{2}$ solution of 6 . ${ }^{1} \mathrm{H}$ NMR (acetone- $\left.d_{6}, 360 \mathrm{MHz}\right): \delta 7.5-7.4\left(\mathrm{~m}, 9 \mathrm{H}, \mathrm{C}_{\mathrm{Ph}}-\mathrm{H}\right)$, $7.32,7.29\left(2 \times \mathrm{d},{ }^{3} J_{\mathrm{HH}}=1.8 \mathrm{~Hz}, 2 \mathrm{H}, \mathrm{C}_{\mathrm{NHC}}-\mathrm{H}\right), 7.2(\mathrm{br}, 6 \mathrm{H}$, $\left.\mathrm{C}_{\mathrm{Ph}}-\mathrm{H}\right), 5.02\left(\mathrm{~s}, 5 \mathrm{H}, \mathrm{H}_{\mathrm{Cp}}\right), 4.3\left(\mathrm{~m}, 2 \mathrm{H}, \mathrm{NCH}_{2}\right), 3.23(\mathrm{~s}, 3 \mathrm{H}$, $\left.\mathrm{NCH}_{3}\right), 2.74\left(\mathrm{~s}, 3 \mathrm{H}, \mathrm{SCH}_{3}\right), 2.5\left(\mathrm{~m}, 1 \mathrm{H}, \mathrm{SCH}_{2}\right), 0.86(\mathrm{~m}, 1 \mathrm{H}$, $\left.\mathrm{SCH}_{2}\right) \cdot{ }^{13} \mathrm{C}\left\{{ }^{1} \mathrm{H}\right\}$ NMR (acetone- $\left.d_{6}, 100 \mathrm{MHz}\right): \delta 177.3\left(\mathrm{~d},{ }^{2} J_{\mathrm{CP}}=\right.$ 15.7 Hz, $\left.\mathrm{C}_{\mathrm{NHC}}-\mathrm{Ru}\right), 137.3\left(\mathrm{~d},{ }^{1} J_{\mathrm{CP}}=43.4 \mathrm{~Hz}, \mathrm{C}_{\mathrm{Ph}}-\mathrm{P}\right), 134.1(\mathrm{~d}$, $\left.J_{\mathrm{CP}}=9.6 \mathrm{~Hz}, \mathrm{C}_{\mathrm{Ph}}-\mathrm{H}\right), 130.8\left(\mathrm{C}_{\mathrm{Ph}}-\mathrm{H}\right), 129.3\left(\mathrm{~d}, J_{\mathrm{CP}}=9.3 \mathrm{~Hz}\right.$, $\left.\mathrm{C}_{\mathrm{Ph}}-\mathrm{H}\right), 125.2,123.6\left(2 \times \mathrm{C}_{\mathrm{NHC}}-\mathrm{H}\right), 81.2\left(\mathrm{C}_{\mathrm{Cp}}\right), 48.1\left(\mathrm{NCH}_{2}\right)$, $38.2\left(\mathrm{NCH}_{3}\right), 32.9\left(\mathrm{SCH}_{2}\right), 28.1\left(\mathrm{SCH}_{3}\right) .{ }^{31} \mathrm{P} \mathrm{NMR}$ (acetone- $d_{6}$, $162 \mathrm{MHz}): \delta 52.7\left(\mathrm{PPh}_{3}\right)$. MS(ESI) $m / z: 585.1\left[\mathrm{M}-\mathrm{BF}_{4}\right]^{+}$. Anal. Calcd for $\mathrm{C}_{30} \mathrm{H}_{32} \mathrm{BF}_{4} \mathrm{~N}_{2} \mathrm{PRuS}(671.51) \times 2 \mathrm{H}_{2} \mathrm{O}$ : C 50.93, H 5.13, N 3.96. Found: C 50.91, H 4.75, N 3.90.

Synthesis of Complex 7. A solution of $3(0.21 \mathrm{~g}, 0.84 \mathrm{mmol})$ in acetone $(100 \mathrm{~mL})$ was treated with $\mathrm{Ag}_{2} \mathrm{O}(0.12 \mathrm{~g}, 0.50 \mathrm{mmol})$, and the suspension was stirred at reflux for $24 \mathrm{~h}$ under exclusion of light. After filtration, $\left[\mathrm{RuCl}(\mathrm{Cp})\left(\mathrm{PPh}_{3}\right)_{2}\right](0.55 \mathrm{~g}, 0.76 \mathrm{mmol})$ was added as a solid and the solution was heated to reflux for $6 \mathrm{~h}$. The mixture was subsequently filtered over a pad of Celite and concentrated until a precipitate started to appear. The supernatant was separated and purified by column chromatography $\left(\mathrm{SiO}_{2}\right.$, first $\mathrm{Et}_{2} \mathrm{O}$, then acetone/MeOH, 3:1). Evaporation of all volatiles from the acetone/MeOH fraction gave complex 7 as a microanalytically pure yellow powder $(228 \mathrm{mg}, 45 \%) .{ }^{1} \mathrm{H}$ NMR $\left(\mathrm{CDCl}_{3}, 500 \mathrm{MHz}\right): \delta 7.4-7.2\left(\mathrm{~m}, 15 \mathrm{H}, \mathrm{C}_{\mathrm{Ph}}-\mathrm{H}\right), 7.01(\mathrm{~s}, 1 \mathrm{H}$, $\left.\mathrm{C}_{\text {mes }}-\mathrm{H}\right), 6.84,6.82\left(2 \times \mathrm{d},{ }^{3} J_{\mathrm{HH}}=1.9 \mathrm{~Hz}, 2 \mathrm{H}, \mathrm{C}_{\mathrm{NHC}}-\mathrm{H}\right), 6.76$ $\left(\mathrm{s}, 1 \mathrm{H}, \mathrm{C}_{\mathrm{mes}}-\mathrm{H}\right), 4.10\left(\mathrm{~d},{ }^{2} J_{\mathrm{HH}}=16.5 \mathrm{~Hz}, 1 \mathrm{H}, \mathrm{NCH}_{2}\right), 3.97$ $\left(\mathrm{s}, 5 \mathrm{H}, \mathrm{H}_{\mathrm{Cp}}\right), 2.82\left(\mathrm{~d},{ }^{2} J_{\mathrm{HH}}=16.5 \mathrm{~Hz}, 1 \mathrm{H}, \mathrm{NCH}_{2}\right), 2.37,2.13$, $1.57\left(3 \times \mathrm{s}, 9 \mathrm{H}, \mathrm{C}_{\mathrm{mes}}-\mathrm{CH}_{3}\right) .{ }^{13} \mathrm{C}\left\{{ }^{1} \mathrm{H}\right\} \mathrm{NMR}\left(\mathrm{CDCl}_{3}, 125 \mathrm{MHz}\right)$ : $\delta 186.6\left(\mathrm{~d},{ }^{2} J_{\mathrm{CP}}=16.8 \mathrm{~Hz}, \mathrm{C}_{\mathrm{NHC}}-\mathrm{Ru}\right), 171.4(\mathrm{C}=\mathrm{O}), 138.9$, $138.4\left(2 \times \mathrm{C}_{\mathrm{mes}}\right), 138.0\left(\mathrm{~d},{ }^{1} J_{\mathrm{CP}}=37.1 \mathrm{~Hz}, \mathrm{C}_{\mathrm{Ph}}-\mathrm{P}\right), 136.7,136.1$ $\left(2 \times \mathrm{C}_{\text {mes }}\right), 133.8\left(\mathrm{~d}, J_{\mathrm{CP}}=10.9 \mathrm{~Hz}, \mathrm{C}_{\mathrm{Ph}}-\mathrm{H}\right), 129.3,129.3(2 \times$ $\left.\mathrm{C}_{\mathrm{mes}}-\mathrm{H}\right), 129.1\left(\mathrm{~d}, J_{\mathrm{CP}}=6.6 \mathrm{~Hz}, \mathrm{C}_{\mathrm{Ph}}-\mathrm{H}\right), 128.0\left(\mathrm{~d}, J_{\mathrm{CP}}=9.1 \mathrm{~Hz}\right.$, $\left.\mathrm{C}_{\mathrm{Ph}}-\mathrm{H}\right), 122.72,122.69\left(2 \times \mathrm{C}_{\mathrm{NHC}}-\mathrm{H}\right), 77.3\left(\mathrm{C}_{\mathrm{Cp}}\right), 53.7$ $\left(\mathrm{NCH}_{2}\right), 21.2,19.6,18.7\left(3 \times \mathrm{C}_{\text {mes }}-\mathrm{CH}_{3}\right) .{ }^{31} \mathrm{P}$ NMR (acetone$\left.d_{6}, 162 \mathrm{MHz}\right): \delta 49.8\left(\mathrm{PPh}_{3}\right)$. IR $(\mathrm{KBr}): v 1628 \mathrm{~cm}^{-1}(\mathrm{C}=\mathrm{O})$. Anal. Calcd for $\mathrm{C}_{37} \mathrm{H}_{35} \mathrm{~N}_{2} \mathrm{O}_{2} \mathrm{PRu}(671.74) \times 1.5 \mathrm{H}_{2} \mathrm{O}: \mathrm{C} 63.60$, H 5.48, N 4.01. Found: C 63.83, H 5.42, N 4.04.

Synthesis of Complex 8. The silver carbene was prepared as for 5a starting from $1(260 \mathrm{mg}, 1.25 \mathrm{mmol})$ and $\mathrm{Ag}_{2} \mathrm{O}(0.15 \mathrm{~g}$, $0.62 \mathrm{mmol})$. The filtrate was added to a solution of $\left[\mathrm{RuCl}_{2}\left(\eta^{6}-p\right.\right.$ cymene $)]_{2}(0.39 \mathrm{~g}, 0.62 \mathrm{mmol})$ in $\mathrm{CH}_{2} \mathrm{Cl}_{2}(10 \mathrm{~mL})$. A precipitate formed immediately and stirring was continued for $4 \mathrm{~h}$. The yellow precipitate was collected by filtration, suspended in $\mathrm{MeCN}(15 \mathrm{~mL})$, and stirred with $\mathrm{KBF}_{4}(470 \mathrm{mg}, 3.74 \mathrm{mmol})$ for $2 \mathrm{~h}$. $\mathrm{Et}_{2} \mathrm{O}(20 \mathrm{~mL})$ was added, and the mixture was filtered over Celite. The filtrate was evaporated to dryness and purified by repetitive precipitation with $\mathrm{CH}_{2} \mathrm{Cl}_{2} / \mathrm{Et}_{2} \mathrm{O}(3 \times)$. After drying in vacuo, 8 was obtained as a yellow solid (272 $\mathrm{mg}, 45 \%)$. ${ }^{1} \mathrm{H}$ NMR (acetone- $d_{6}, 360 \mathrm{MHz}$ ): major isomer, $\delta 7.41,7.36$ $\left(2 \times \mathrm{d},{ }^{3} J_{\mathrm{HH}}=1.8 \mathrm{~Hz}, 2 \mathrm{H}, \mathrm{C}_{\mathrm{NHC}}-\mathrm{H}\right), 6.83,6.72,6.18,6.15(4 \times$ $\left.\mathrm{d},{ }^{3} J_{\mathrm{HH}}=6.3 \mathrm{~Hz}, 4 \mathrm{H}, \mathrm{C}_{\mathrm{cym}}-\mathrm{H}\right), 5.90\left(\mathrm{~m}, 1 \mathrm{H}, \mathrm{CH}=\mathrm{CH}_{2}\right), 5.21(\mathrm{~d}$, $\left.{ }^{3} J_{\mathrm{HH}}=8.9 \mathrm{~Hz}, 1 \mathrm{H}, C=\mathrm{CH}_{2}\right), 4.60\left(\mathrm{dd},{ }^{2} J_{\mathrm{HH}}=13.0,{ }^{3} J_{\mathrm{HH}}=6.5\right.$ $\left.\mathrm{Hz}, 1 \mathrm{H}, \mathrm{NCH}_{2}\right), 4.12\left(\mathrm{dd},{ }^{2} J_{\mathrm{HH}}=13.0,3^{3} J_{\mathrm{HH}}=3.9 \mathrm{~Hz}, 1 \mathrm{H}\right.$, $\left.\mathrm{NCH}_{2}\right), 3.95\left(\mathrm{~s}, 3 \mathrm{H}, \mathrm{NCH}_{3}\right), 3.35\left(\mathrm{~d},{ }^{3} J_{\mathrm{HH}}=13.4 \mathrm{~Hz}, 1 \mathrm{H}\right.$, $\left.C=\mathrm{CH}_{2}\right), 2.80\left(\mathrm{~m},{ }^{3} J_{\mathrm{HH}}=6.9 \mathrm{~Hz}, 1 \mathrm{H}, \mathrm{CHMe}_{2}\right), 2.26(\mathrm{~s}, 3 \mathrm{H}$, $\left.\mathrm{C}_{\mathrm{cym}}-\mathrm{CH}_{3}\right), 1.25\left(\mathrm{~d},{ }^{3} J_{\mathrm{HH}}=6.9 \mathrm{~Hz}, 3 \mathrm{H}, \mathrm{CH}\left(\mathrm{CH}_{3}\right)_{2}\right), 1.15(\mathrm{~d}$, $\left.{ }^{3} J_{\mathrm{HH}}=6.9 \mathrm{~Hz}, 3 \mathrm{H}, \mathrm{CH}\left(\mathrm{CH}_{3}\right)_{2}\right)$. Minor isomer: $\delta 7.41,7.36(2 \times$ $\left.\mathrm{d},{ }^{3} J_{\mathrm{HH}}=1.8 \mathrm{~Hz}, 2 \mathrm{H}, \mathrm{C}_{\mathrm{NHC}}-\mathrm{H}\right), 6.76,6.66,6.23,6.18(4 \times \mathrm{d}$, $\left.{ }^{3} J_{\mathrm{HH}}=6.4 \mathrm{~Hz}, 4 \mathrm{H}, \mathrm{C}_{\mathrm{cym}}-\mathrm{H}\right), 5.80\left(\mathrm{~m}, 1 \mathrm{H}, \mathrm{CH}=\mathrm{CH}_{2}\right), 5.06(\mathrm{~d}$, $\left.{ }^{3} J_{\mathrm{HH}}=8.9 \mathrm{~Hz}, 1 \mathrm{H}, C=\mathrm{CH}_{2}\right), 4.60\left(\mathrm{dd},{ }^{2} J_{\mathrm{HH}}=13.0,{ }^{3} J_{\mathrm{HH}}=6.5\right.$ $\left.\mathrm{Hz}, 1 \mathrm{H}, \mathrm{NCH}_{2}\right), 4.04\left(\mathrm{dd},{ }^{2} J_{\mathrm{HH}}=12.7,{ }^{3} J_{\mathrm{HH}}=4.5 \mathrm{~Hz}, 1 \mathrm{H}\right.$, $\left.\mathrm{NCH}_{2}\right), 3.95\left(\mathrm{~s}, 3 \mathrm{H}, \mathrm{NCH}_{3}\right), 3.60\left(\mathrm{~d},{ }^{3} J_{\mathrm{HH}}=13.4 \mathrm{~Hz}, 1 \mathrm{H}\right.$, $\left.C=\mathrm{CH}_{2}\right), 2.80\left(\mathrm{~m},{ }^{3} J_{\mathrm{HH}}=6.9 \mathrm{~Hz}, 1 \mathrm{H}, \mathrm{CHMe}_{2}\right), 2.35(\mathrm{~s}, 3 \mathrm{H}$, $\left.\mathrm{C}_{\mathrm{cym}}-\mathrm{CH}_{3}\right), 2.26\left(\mathrm{~s}, 3 \mathrm{H}, \mathrm{C}_{\mathrm{cym}}-\mathrm{CH}_{3}\right), 1.25\left(\mathrm{~d},{ }^{3} J_{\mathrm{HH}}=6.9 \mathrm{~Hz}\right.$, $\left.3 \mathrm{H}, \mathrm{CH}\left(\mathrm{CH}_{3}\right)_{2}\right), 1.15\left(\mathrm{~d},{ }^{3} J_{\mathrm{HH}}=6.9 \mathrm{~Hz}, 3 \mathrm{H}, \mathrm{CH}\left(\mathrm{CH}_{3}\right)_{2}\right)$. ${ }^{13} \mathrm{C}\left\{{ }^{1} \mathrm{H}\right\}$ NMR (DMSO-d $d_{6}, 125 \mathrm{MHz}$, major isomer only): $\delta 167.1\left(\mathrm{C}_{\mathrm{NHC}}-\mathrm{Ru}\right), 125.8,119.8\left(2 \times \mathrm{C}_{\mathrm{NHC}}-\mathrm{H}\right), 114.5,111.9$ $\left(2 \times C_{c y m}-\mathrm{C}\right), 99.1,96.8,95.1,94.6\left(4 \times \mathrm{C}_{\mathrm{cym}}-\mathrm{H}\right) 79.3$ $\left(\mathrm{CH}=\mathrm{CH}_{2}\right), 67.2\left(\mathrm{C}=\mathrm{CH}_{2}\right), 48.4\left(\mathrm{NCH}_{2}\right), 37.2\left(\mathrm{NCH}_{3}\right), 33.0$ $\left(\mathrm{CHMe}_{2}\right), 23.8,20.1\left(2 \times \mathrm{CH}\left(\mathrm{CH}_{3}\right)_{2}\right) 17.9\left(\mathrm{C}_{\mathrm{cym}}-\mathrm{CH}_{3}\right)$. Anal. Calcd for $\mathrm{C}_{17} \mathrm{H}_{24} \mathrm{BClF}_{4} \mathrm{~N}_{2} \mathrm{Ru}(479.72) \times \mathrm{H}_{2} \mathrm{O}: \mathrm{C} 41.02, \mathrm{H}$ 5.27, N 5.63. Found: C 41.00, H 5.00, N 5.99.

Synthesis of Complex 9. The silver carbene was prepared as for 6 starting from 2 (284 mg, $1.47 \mathrm{mmol})$ and $\mathrm{Ag}_{2} \mathrm{O}(0.20 \mathrm{~g}$, $0.88 \mathrm{mmol})$. The filtrate $(60 \mathrm{~mL})$ was added to $\left[\mathrm{RuCl}_{2}\left(\eta^{6}-\right.\right.$ $p$-cymene $)]_{2}(0.37 \mathrm{~g}, 0.59 \mathrm{mmol})$ dissolved in $\mathrm{CH}_{2} \mathrm{Cl}_{2}(20 \mathrm{~mL})$. A precipitate formed and stirring was continued for $5 \mathrm{~h}$. The crude mixture was filtered over a pad of Celite and concentrated to $30 \mathrm{~mL}$. Addition of $\mathrm{Et}_{2} \mathrm{O}(30 \mathrm{~mL})$ induced the formation of a precipitate, which was collected by filtration and purified by repeated precipitation from $\mathrm{CH}_{2} \mathrm{Cl}_{2}(7 \mathrm{~mL})$ and $\mathrm{Et}_{2} \mathrm{O}(50 \mathrm{~mL})$. The yellow solid was dissolved in $\mathrm{CH}_{2} \mathrm{Cl}_{2}(4 \mathrm{~mL})$ and added to $\mathrm{KBF}_{4}$ (196 mg, $\left.1.52 \mathrm{mmol}\right)$ suspended in acetone $(15 \mathrm{~mL})$. The mixture was stirred for $2 \mathrm{~h}$ before adding $\mathrm{Et}_{2} \mathrm{O}(15 \mathrm{~mL})$. After filtration the filtrate was concentrated to $5 \mathrm{~mL}$ and the product precipitated upon addition of $\mathrm{Et}_{2} \mathrm{O}(30 \mathrm{~mL})$. The residue was dissolved in a minimum amount of $\mathrm{CH}_{2} \mathrm{Cl}_{2}$, filtered over Celite, and evaporated to dryness, thus yielding 9 (190 mg, 26\%). ${ }^{1} \mathrm{H}$ NMR (acetone- $\left.d_{6}, 500 \mathrm{MHz}\right): \delta 7.48\left(\mathrm{~d},{ }^{3} J_{\mathrm{HH}}=1.9 \mathrm{~Hz}\right.$, $\left.1 \mathrm{H}, \mathrm{C}_{\mathrm{NHC}}-\mathrm{H}\right), 7.46\left(\mathrm{~s}, 1 \mathrm{H}, \mathrm{C}_{\mathrm{NHC}}-\mathrm{H}\right), 6.20,6.14,5.89,5.69(4 \times$ $\left.\mathrm{d},{ }^{3} J_{\mathrm{HH}}=5.9 \mathrm{~Hz}, 4 \mathrm{H}, \mathrm{C}_{\mathrm{cym}}-\mathrm{H}\right), 4.68\left(\mathrm{~m}, 1 \mathrm{H}, \mathrm{NCH}_{2}\right), 4.04(\mathrm{~s}$, $\left.3 \mathrm{H}, \mathrm{NCH}_{3}\right), 3.86\left(\mathrm{~m}, 1 \mathrm{H}, \mathrm{NCH}_{2}\right), 2.83\left(\mathrm{~m}, 1 \mathrm{H}, \mathrm{CHMe}_{2}\right), 3.42$ (m, $\left.1 \mathrm{H}, \mathrm{CH}_{2} \mathrm{~S}\right), 2.24\left(\mathrm{~s}, 3 \mathrm{H}, \mathrm{C}_{\mathrm{cym}}-\mathrm{CH}_{3}\right.$ or $\left.\mathrm{SCH}_{3}\right), 2.17(\mathrm{~m}, 1 \mathrm{H}$, $\left.\mathrm{CH}_{2} \mathrm{~S}\right), 2.09\left(\mathrm{~s}, 3 \mathrm{H}, \mathrm{SCH}_{3}\right.$ or $\left.\mathrm{C}_{\mathrm{cym}}-\mathrm{CH}_{3}\right), 1.29,1.18(2 \times \mathrm{d}$, $\left.{ }^{3} J_{\mathrm{HH}}=6.7 \mathrm{~Hz}, 6 \mathrm{H}, \mathrm{CH}\left(\mathrm{CH}_{3}\right)_{2}\right) .{ }^{13} \mathrm{C}\left\{{ }^{1} \mathrm{H}\right\}$ NMR (acetone- $d_{6}, 100$ $\mathrm{MHz}): \delta 169.3\left(\mathrm{C}_{\mathrm{NHC}}-\mathrm{Ru}\right), 125.1,124.7\left(2 \times \mathrm{C}_{\mathrm{NHC}}-\mathrm{H}\right), 113.7$, $104.5\left(2 \times C_{c y m}-\mathrm{C}\right), 91.6,91.1,89.3,87.8\left(4 \times \mathrm{C}_{\mathrm{cym}}-\mathrm{H}\right)$, $49.0\left(\mathrm{NCH}_{2}\right), 39.1\left(\mathrm{NCH}_{3}\right), 35.1\left(\mathrm{CH}_{2} \mathrm{~S}\right), 31.6\left(\mathrm{CHMe}_{2}\right), 23.9$, 
$21.1\left(2 \times \mathrm{CH}\left(\mathrm{CH}_{3}\right)_{2}\right), 20.2,18.2\left(\mathrm{C}_{\mathrm{cym}}-\mathrm{CH}_{3}\right.$ and $\left.\mathrm{SCH}_{3}\right)$. Anal. Calcd for $\mathrm{C}_{17} \mathrm{H}_{26} \mathrm{BClF}_{4} \mathrm{~N}_{2} \mathrm{RuS}(513.80) \times \mathrm{H}_{2} \mathrm{O}$ : C 38.39, H 5.31, N 5.27. Found: C 38.63, H 5.10, N 5.17.

Synthesis of Complex 10. The silver carbene complex was prepared as for 7 starting from $3(359 \mathrm{mg}, 1.47 \mathrm{mmol})$ and $\mathrm{Ag}_{2} \mathrm{O}$ $(0.20 \mathrm{~g}, 0.88 \mathrm{mmol})$. The filtrate was concentrated to $100 \mathrm{~mL}$ and $\left[\mathrm{RuCl}_{2}\left(\eta^{6} \text {-p-cymene }\right)\right]_{2}$ (460 $\left.\mathrm{mg}, 0.74 \mathrm{mmol}\right)$ was added. After stirring for $18 \mathrm{~h}$ at RT, the crude mixture was filtered over a pad of Celite and concentrated to $50 \mathrm{~mL}$. Upon storage of the filtrate at $-30{ }^{\circ} \mathrm{C}$ a red microcrystalline solid formed. This solid was collected by centrifugation and recrystallized from warm acetone $(20 \mathrm{~mL})$ at $-30{ }^{\circ} \mathrm{C}$. Redissolution in $\mathrm{CH}_{2} \mathrm{Cl}_{2}$, filtration over Celite, and removal of the volatiles in vacuo afforded 10 in microanalytical purity $(410 \mathrm{mg}, 52 \%)$. Crystals suitable for X-ray diffraction were grown from an acetone solution at $-30{ }^{\circ} \mathrm{C} .{ }^{1} \mathrm{H}$ NMR $\left(\mathrm{CDCl}_{3}, 500 \mathrm{MHz}\right): \delta 7.16,7.08(2 \times \mathrm{s}$, $\left.2 \mathrm{H}, \mathrm{C}_{\mathrm{mes}}-\mathrm{H}\right), 6.96,6.88\left(2 \times \mathrm{d},{ }^{3} J_{\mathrm{HH}}=1.8 \mathrm{~Hz}, 2 \mathrm{H}, \mathrm{C}_{\mathrm{NHC}}-\mathrm{H}\right)$, $5.60\left(\mathrm{~d},{ }^{3} J_{\mathrm{HH}}=6.5 \mathrm{~Hz}, 1 \mathrm{H}, \mathrm{C}_{\mathrm{cym}}-\mathrm{H}\right), 5.50\left(\mathrm{br}, 1 \mathrm{H}, \mathrm{C}_{\mathrm{cym}}-\mathrm{H}\right)$, $5.00\left(\mathrm{~d},{ }^{2} J_{\mathrm{HH}}=15.5 \mathrm{~Hz}, 1 \mathrm{H}, \mathrm{NCH}_{2}\right), 4.95\left(\mathrm{~d},{ }^{3} J_{\mathrm{HH}}=4.3 \mathrm{~Hz}, 1 \mathrm{H}\right.$, $\left.\mathrm{C}_{\mathrm{cym}}-\mathrm{H}\right), 4.23\left(\mathrm{~d},{ }^{2} J_{\mathrm{HH}}=15.5 \mathrm{~Hz}, 1 \mathrm{H}, \mathrm{NCH}_{2}\right), 3.34(\mathrm{br}, 1 \mathrm{H}$, $\left.\mathrm{C}_{\text {cym }}-\mathrm{H}\right), 2.72\left(\mathrm{sept},{ }^{3} J_{\mathrm{HH}}=6.9 \mathrm{~Hz}, 1 \mathrm{H}, \mathrm{CHMe}_{2}\right), 2.43,2.29$, $2.05\left(3 \times \mathrm{s}, 9 \mathrm{H}, \mathrm{C}_{\mathrm{mes}}-\mathrm{CH}_{3}\right), 1.81\left(\mathrm{~s}, 3 \mathrm{H}, \mathrm{C}_{\mathrm{cym}}-\mathrm{CH}_{3}\right), 1.15,0.96$ $\left(2 \times \mathrm{d},{ }^{3} J_{\mathrm{HH}}=6.9 \mathrm{~Hz}, 6 \mathrm{H}, \mathrm{CH}\left(\mathrm{CH}_{3}\right)_{2}\right) .{ }^{13} \mathrm{C}\left\{{ }^{1} \mathrm{H}\right\} \mathrm{NMR}\left(\mathrm{CDCl}_{3}\right.$, $125 \mathrm{MHz}): \delta 171.1(\mathrm{C}=\mathrm{O}), 171.0\left(\mathrm{C}_{\mathrm{NHC}}-\mathrm{Ru}\right), 140.5,138.0$, 137.4, $135.0\left(4 \times \mathrm{C}_{\text {mes }}\right), 129.5,129.3\left(2 \times \mathrm{C}_{\text {mes }}-\mathrm{H}\right), 123.0,121.9$ $\left(2 \times \mathrm{C}_{\mathrm{NHC}}-\mathrm{H}\right), 102.4,92.8\left(2 \times C_{c \mathrm{~cm}}-\mathrm{C}\right), 96\left(\mathrm{br}, \mathrm{C}_{\mathrm{cym}}-\mathrm{H}\right)$, $54.6\left(\mathrm{NCH}_{2}\right), 29.3\left(\mathrm{CHMe}_{2}\right), 23.4\left(\mathrm{CH}\left(\mathrm{CH}_{3}\right) \mathrm{Me}\right), 21.2\left(\mathrm{C}_{\mathrm{mes}}-\right.$ $\left.\mathrm{CH}_{3}\right), 20.3\left(\mathrm{CHMe}\left(\mathrm{CH}_{3}\right)\right), 18.6,18.1\left(2 \times \mathrm{C}_{\text {mes }}-\mathrm{CH}_{3}\right), 17.7$ $\left(\mathrm{C}_{\mathrm{cym}}-\mathrm{CH}_{3}\right)$. IR $(\mathrm{KBr}): v 1630 \mathrm{~cm}^{-1}(\mathrm{C}=\mathrm{O})$. Anal. Calcd for $\mathrm{C}_{24} \mathrm{H}_{29} \mathrm{ClN}_{2} \mathrm{O}_{2} \mathrm{Ru}(514.03) \times 1.5 \mathrm{H}_{2} \mathrm{O}: \mathrm{C} 53.28, \mathrm{H} 5.96, \mathrm{~N} 5.18$. Found: C 53.19, H 5.99, N 5.28.

Synthesis of Complex 11. A solution of $4(0.49 \mathrm{~g}, 1.0 \mathrm{mmol})$ in $\mathrm{H}_{2} \mathrm{O}(15 \mathrm{~mL})$ was treated with $\mathrm{Ag}_{2} \mathrm{O}(0.58 \mathrm{~g}, 2.5 \mathrm{mmol})$. After 30 min stirring at RT under exclusion of light, the suspension was filtered over Celite. Addition of an aqueous solution of $\mathrm{NH}_{4} \mathrm{PF}_{6}(1.3 \mathrm{~g}, 8.0 \mathrm{mmol})$ to the filtrate induced the formation of a white precipitate, which was subsequently washed with $\mathrm{H}_{2} \mathrm{O}$ $(2 \times 60 \mathrm{~mL})$ and then with $\mathrm{Et}_{2} \mathrm{O}(2 \times 30 \mathrm{~mL})$. The residue was dissolved in $\mathrm{CH}_{2} \mathrm{Cl}_{2}(30 \mathrm{~mL})$ and solid $\left[\mathrm{RuCl}_{2}\left(\eta^{6} \text {-benzene }\right)\right]_{2}$ $(0.30 \mathrm{~g}, 0.50 \mathrm{mmol})$ was added. The mixture was stirred for $18 \mathrm{~h}$ at RT. Precipitation with $\mathrm{Et}_{2} \mathrm{O}(80 \mathrm{~mL})$ and reprecipitation from $\mathrm{CH}_{2} \mathrm{Cl}_{2} / \mathrm{Et}_{2} \mathrm{O}$ 1:4 (100 mL) afforded crude $11(0.44 \mathrm{~g}, 72 \%)$. Column chromatography $\left(\mathrm{SiO}_{2}\right.$, acetone/ $\left.\mathrm{Et}_{2} \mathrm{O}, 1: 4\right)$ gave a microanalytically pure sample. ${ }^{1} \mathrm{H}$ NMR (DMSO- $d_{6}, 500$ $\mathrm{MHz}): \delta 7.73,7.61\left(2 \times \mathrm{d},{ }^{3} J_{\mathrm{HH}}=2.0 \mathrm{~Hz}, 4 \mathrm{H}, \mathrm{C}_{\mathrm{NHC}}-\mathrm{H}\right), 6.22$ $\left(\mathrm{d},{ }^{2} J_{\mathrm{HH}}=12.9 \mathrm{~Hz}, 1 \mathrm{H}, \mathrm{NCH}_{2}\right), 5.90\left(\mathrm{~s}, 6 \mathrm{H}, \mathrm{C}_{\mathrm{ar}}-\mathrm{H}\right), 5.61(\mathrm{~d}$, $\left.{ }^{2} J_{\mathrm{HH}}=12.9 \mathrm{~Hz}, 1 \mathrm{H}, \mathrm{NCH}_{2}\right), 5.28\left(\mathrm{sept},{ }^{3} J_{\mathrm{HH}}=6.7 \mathrm{~Hz}, 2 \mathrm{H}\right.$, $\left.\mathrm{CHMe}_{2}\right), 1.58,1.32\left(2 \times \mathrm{d},{ }^{3} \mathrm{~J}_{\mathrm{HH}}=6.7 \mathrm{~Hz}, 12 \mathrm{H}, \mathrm{CH}\left(\mathrm{CH}_{3}\right)_{2}\right)$. ${ }^{13} \mathrm{C}\left\{{ }^{1} \mathrm{H}\right\}$ NMR (DMSO- $\left.d_{6}, 125 \mathrm{MHz}\right): \delta 171.8\left(\mathrm{C}_{\mathrm{NHC}}-\mathrm{Ru}\right)$, 122.2, $119.2\left(2 \times \mathrm{C}_{\mathrm{NHC}}-\mathrm{H}\right), 89.6\left(\mathrm{C}_{\mathrm{ar}}\right), 60.9\left(\mathrm{NCH}_{2}\right), 51.9$ $\left(\mathrm{CHMe}_{2}\right), 23.8,22.6\left(2 \times \mathrm{CH}\left(\mathrm{CH}_{3}\right)_{2}\right)$. Anal. Calcd for $\mathrm{C}_{19^{-}}$ $\mathrm{H}_{26} \mathrm{ClF}_{6} \mathrm{~N}_{4} \mathrm{PRu}(591.93) \times \mathrm{H}_{2} \mathrm{O}: \mathrm{C} 37.41, \mathrm{H} 4.63, \mathrm{~N} 9.19$. Found: C 37.10, H 4.76, N 8.97.

Synthesis of Complex 12. In analogy to 11, complex 12 was prepared from $4(0.54 \mathrm{~g}, 1.1 \mathrm{mmol})$ and $\mathrm{Ag}_{2} \mathrm{O}(0.64 \mathrm{~g}, 2.7 \mathrm{mmol})$ in $\mathrm{H}_{2} \mathrm{O}(15 \mathrm{~mL})$, and $\left[\mathrm{RuCl}_{2}\left(\eta^{6}-p \text {-cymene }\right)\right]_{2}(0.34 \mathrm{~g}, 0.55 \mathrm{mmol})$ in $\mathrm{CH}_{2} \mathrm{Cl}_{2}(30 \mathrm{~mL})$. The mixture was filtered through Celite, concentrated to $10 \mathrm{~mL}$, and precipitated with $\mathrm{Et}_{2} \mathrm{O}(80 \mathrm{~mL})$. The residue was precipitated twice more from $\mathrm{CH}_{2} \mathrm{Cl}_{2} / \mathrm{Et}_{2} \mathrm{O}, 1: 4(2 \times$ $100 \mathrm{~mL})$. Column chromatography $\left(\mathrm{SiO}_{2}\right.$, acetone/Et $\left.{ }_{2} \mathrm{O}, 1: 5\right)$ and subsequent precipitation from acetone/pentane $(1: 5,25 \mathrm{~mL})$ afforded $\mathbf{1 2}$ as a microanalytically pure, yellow solid $(70 \mathrm{mg}$, $10 \%$ ). Crystals suitable for X-ray diffraction were grown by liquid/liquid diffusion of pentane into an acetone solution of $\mathbf{1 2}$. ${ }^{1} \mathrm{H} \mathrm{NMR}\left(\mathrm{CDCl}_{3}, 500 \mathrm{MHz}\right): \delta 7.36,7.11\left(2 \times \mathrm{d},{ }^{3} J_{\mathrm{HH}}=2.1 \mathrm{~Hz}\right.$, $\left.4 \mathrm{H}, \mathrm{C}_{\mathrm{NHC}}-\mathrm{H}\right), 6.10\left(\mathrm{~d},{ }^{2} J_{\mathrm{HH}}=13.2 \mathrm{~Hz}, 1 \mathrm{H}, \mathrm{NCH}_{2}\right), 5.60(\mathrm{~s}$, $\left.4 \mathrm{H}, \mathrm{C}_{\mathrm{cym}}-\mathrm{H}\right), 5.43\left(\mathrm{~d},{ }^{2} J_{\mathrm{HH}}=13.2 \mathrm{~Hz}, 1 \mathrm{H}, \mathrm{NCH}_{2}\right), 5.13(\mathrm{sept}$, $\left.{ }^{3} J_{\mathrm{HH}}=6.7 \mathrm{~Hz}, 2 \mathrm{H}, \mathrm{NCHMe}_{2}\right), 2.41\left(\mathrm{sept},{ }^{3} J_{\mathrm{HH}}=6.9 \mathrm{~Hz}\right.$, $\left.1 \mathrm{H}, \mathrm{C}_{\text {cym }}-\mathrm{CHMe}_{2}\right), 2.09\left(\mathrm{~s}, 3 \mathrm{H}, \mathrm{C}_{\text {cym }}-\mathrm{CH}_{3}\right), 1.57,1.38$ $\left(2 \times \mathrm{d},{ }^{3} J_{\mathrm{HH}}=6.7 \mathrm{~Hz}, 12 \mathrm{H}, \mathrm{NCH}\left(\mathrm{CH}_{3}\right)_{2}\right), 1.04\left(\mathrm{~d},{ }^{3} J_{\mathrm{HH}}=6.9\right.$
$\left.\mathrm{Hz}, 6 \mathrm{H}, \mathrm{C}_{\mathrm{cym}}-\mathrm{CH}\left(\mathrm{CH}_{3}\right)_{2}\right) .{ }^{13} \mathrm{C}\left\{{ }^{1} \mathrm{H}\right\} \mathrm{NMR}\left(\mathrm{CDCl}_{3}, 125 \mathrm{MHz}\right)$ : $\delta$ 172.6 $\left(\mathrm{C}_{\mathrm{NHC}}-\mathrm{Ru}\right), 122.6,118.6\left(2 \times \mathrm{C}_{\mathrm{NHC}}-\mathrm{H}\right), 108.0,103.6$ $\left(2 \times C_{c y m}-\mathrm{C}\right), 91.1,86.9\left(2 \times \mathrm{C}_{\text {cym }}-\mathrm{H}\right), 61.6\left(\mathrm{NCH}_{2}\right), 52.4$ $\left(\mathrm{NCHMe}_{2}\right), 32.2\left(\mathrm{C}_{\mathrm{cym}}-\mathrm{CHMe}_{2}\right), 24.5,24.3\left(2 \times \mathrm{NC}\left(\mathrm{CH}_{3}\right)_{2}\right)$, $22.9\left(\mathrm{C}_{\mathrm{cym}}-\mathrm{CH}\left(\mathrm{CH}_{3}\right)_{2}\right)$, $18.6\left(\mathrm{C}_{\mathrm{cym}}-\mathrm{CH}_{3}\right)$. Anal. Calcd for $\mathrm{C}_{23} \mathrm{H}_{34} \mathrm{ClF}_{6} \mathrm{PRu}(648.03) \times 0.5 \mathrm{H}_{2} \mathrm{O}: \mathrm{C} 42.04, \mathrm{H} 5.37, \mathrm{~N} 8.53$. Found: C 42.13, H 5.67, N 8.58.

Typical Procedure for Catalytic Hydrogenation. A mixture of ruthenium complex $(15 \mu \mathrm{mol})$, styrene $(15.0 \mathrm{mmol})$, and octane (2.6 mmol; internal NMR standard) in THF $(6 \mathrm{~mL})$ or in $\mathrm{THF} /$ EtOH $(1: 1,12 \mathrm{~mL})$ was placed into an autoclave and purged once with dihydrogen ( 60 bar). Then the pressure was adjusted to 60 bar, the inlet of the autoclave was closed, and the system was immersed into an oil bath preheated to $80^{\circ} \mathrm{C}$. After given periods (Table 3 ), the autoclave was cooled and the pressure released. An aliquot $(\sim 20 \mu \mathrm{L})$ was dissolved in $\mathrm{CDCl}_{3}$ and analyzed by ${ }^{1} \mathrm{H}$ NMR spectroscopy. Conversions were determined by comparing the product/octane integral ratio. Samples containing polymeric products were purified by trituration with pentane and filtration over a short pad of $\mathrm{SiO}_{2}$ (THF as eluent) and then analyzed by GPC.

High-Pressure NMR Experiment. Measurements were performed on a Bruker DRX 400 spectrometer; the sapphire NMR tubes were homemade with $10 \mathrm{~mm}$ external diameter. ${ }^{39} \mathrm{~A}$ mixture of ruthenium complex $(10 \mu \mathrm{mol})$, styrene $(200 \mu \mathrm{mol})$, and $\mathrm{SiMe}_{4}(22 \mu \mathrm{mol}$; internal NMR standard $)$ in THF- $d_{8} /$ EtOD- $d_{6}(1: 1 \mathrm{v} / \mathrm{v}, 2 \mathrm{~mL})$ was placed into the NMR tube and purged once with dihydrogen (60 bar). Then the $\mathrm{H}_{2}$ pressure was adjusted to 100 bar, and NMR spectra were recorded at $70{ }^{\circ} \mathrm{C}$. Chemical shifts were referenced to $\mathrm{SiMe}_{4}$.

Crystal Structure Determinations. Suitable single crystals were mounted on a Stoe Mark II imaging plate diffractometer system equipped with a graphite monochromator. Data collection was performed at $-100{ }^{\circ} \mathrm{C}$ using Mo $\mathrm{K} \alpha$ radiation $(\lambda=$ $0.71073 \AA$ A) with a nominal crystal to detector distance of $135 \mathrm{~mm}$. All structures were solved by direct methods using the program SHELXS-97 and refined by full matrix leastsquares on $F^{2}$ with SHELXL-97. ${ }^{40}$ The hydrogen atoms in the vinyl groups of 5a were derived from Fourier difference maps and refined with constraints on the $\mathrm{C}-\mathrm{H}$ distances $(0.95(2) \AA)$. All other hydrogen atoms were included in calculated positions and treated as riding atoms using SHELXL-97 default parameters. All non-hydrogen atoms were refined anisotropically. An empirical absorption correction was applied using DELrefABS (PLATON03 ${ }^{41}$ ) for 5a. For the other compounds a semiempirical absorption correction was applied using MULABS (PLATON03).

Compound $\mathbf{5 a}$ crystallized with two Ru complex cations, two chloride anions, two $\mathrm{CH}_{2} \mathrm{Cl}_{2}$, and four $\mathrm{H}_{2} \mathrm{O}$ molecules per asymmetric unit. No hydrogen atoms were found for the crystallized $\mathrm{H}_{2} \mathrm{O}$ molecules, but they were included for all calculations. The structure of $\mathbf{6}$ contains a strongly disordered $\mathrm{CH}_{2} \mathrm{Cl}_{2}$ molecule per complex. It was not possible to find a reasonable model defining the disorder. The SQUEEZE instruction in PLATON03 was therefore used to calculate the potential solvent-accessible area in the unit cell $\left(891 \AA^{3}\right.$ was calculated containing about 312 electrons). Hence, eight $\mathrm{CH}_{2} \mathrm{Cl}_{2}$ molecules $(8 \times 48$ electrons $)$ per unit cell were included in all further calculations. Complex 10 crystallizes with one acetone molecule. The isopropyl moiety of the $p$-cymene ligand shows disorder, and the participating atoms have been refined with occupancies of 0.5. Further details on data collection and refinement parameters are collected in the Supporting Information. Crystallographic data (excluding structure factors) for the structures 5a, 6, 10, and $\mathbf{1 2}$ have been deposited with the Cambridge

(39) Cusanelli, A.; Frey, U.; Richens, D. T.; Merbach, A. E. J. Am. Chem. Soc. 1996, 118, 5265 .

(40) Sheldrick, G. M. Acta Crystallogr. A 2008, 64, 112.

(41) Spek, A. L. J. Appl. Crystallogr. 2003, 36, 7. 
Crystallographic Data Centre as supplementary publication nos. CCDC 730480-730483. Copies of the data can be obtained free of charge on application to CCDS, 12 Union Road, Cambridge CB2 1EZ, UK [fax: (int.) +44-1223-336-033; e-mail: deposit@ccds.cam.ac.uk].

Acknowledgment. We thank Ms. A. Schuwey for technical assistance. This research was supported by ERA-net
Chemistry. M.A. is very grateful for an Alfred Werner Assistant Professorship.

Supporting Information Available: Plots of stability measurements of complexes $\mathbf{8}$ and $\mathbf{1 0}$ in the absence of styrene; crystallographic data for complexes 5a, 6, 10, and $\mathbf{1 2}$ in CIF format. 